\title{
Letter Report: LAW Simulant Development for Cast Stone Screening Tests
}
RL Russell
AD Cozzi
JH Westsik, Jr.
MJ Lindberg
DJ Swanberg
GB Josephson
RE Eibling
DE Rinehart

March 2013

\section{Pacific Northwest}

NATIONAL LABORATORY

Proudly Operated by Battelle Since 1965 



\title{
DISCLAIMER
}

This report was prepared as an account of work sponsored by an agency of the United States Government. Neither the United States Government nor any agency thercof, nor Battelle Memorial Institute, nor any of their employees, makes any warranty, express or implied, or assumes any legal liability or responsibility for the accuracy, completeness, or usefulness of any information, apparatus, product, or process disclosed, or represents that its use would not infringe privately owned rights. Reference herein to any specific commercial product, process, or service by trade name, trademark, manufacturer, or otherwise does not necessarily constitute or imply its endorsement, recommendation, or favoring by the United States Government or any agency thereof, or Battelle Memorial Institute. The views and opinions of authors expressed herein do not necessarily state or reflect those of the United States Government or any agency thereof.

\author{
PACIFIC NORTHWEST NATIONAL LABORATORY \\ operated by \\ BATTELLE \\ for the \\ UNITED STATES DEPARTMENT OF ENERGY \\ under Contract DE-AC05-76RL01830
}

\author{
Printed in the United States of America \\ Available to DOE and DOE contractors from the \\ Office of Scientific and Technical Information, \\ P.O. Box 62, Oak Ridge, TN 37831-0062; \\ ph: (865) 576-8401 \\ fax: $(865) 576-5728$ \\ email: reports@adonis.osti.gov \\ Available to the public from the National Technical Information Service \\ 5301 Shawnee Rd., Alexandria, VA 22312 \\ ph: (800) 553-NTIS (6847) \\ email: orders $a$ ntis.gov $<$ http://www.ntis.gov/about/form.aspx $>$ \\ Online ordering: http://www.ntis.gov
}

This document was printed on recycled paper. 

PNNL-22352

\title{
Letter Report: LAW Simulant Development for Cast Stone Screening Tests
}

\author{
RL Russell \\ JH Westsik, Jr. \\ DJ Swanberg ${ }^{1}$ \\ RE Eibling ${ }^{2}$ \\ A Cozzi $^{2}$ \\ MJ Lindberg \\ GB Josephson \\ DE Rinehart
}

March 2013

Prepared for

the U.S. Department of Energy

under Contract DE-AC05-76RL01830

Pacific Northwest National Laboratory

Richland, Washington 99352

\footnotetext{
${ }^{1}$ Washington River Protection Solutions, Richland, Washington.

${ }^{2}$ Savannah River National Laboratory, Aiken, South Carolina.
} 



\section{Acronyms and Abbreviations}

COC

DST

EPA

FY

HLW

HTWOS

ICP

IDF

LAW

OES

PNNL

RCRA

SRNL

SST

TOC

UTS

WTP

XRD constituent of concern

double-shell tank

U.S. Environmental Protection Agency

fiscal year

high-level waste

Hanford Tank Waste Operations Simulator

inductively coupled plasma

Integrated Disposal Facility

low-activity waste

optical emission spectroscopy

Pacific Northwest National Laboratory

Resource Conservation and Recovery Act of 1976

Savannah River National Laboratory

single-shell tank

total organic carbon

Universal Treatment Standards

Hanford Tank Waste Treatment and Immobilization Plant

$\mathrm{x}$-ray diffraction 



\section{Contents}

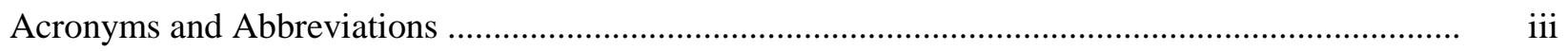

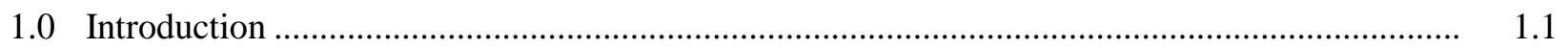

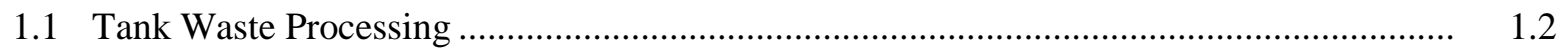

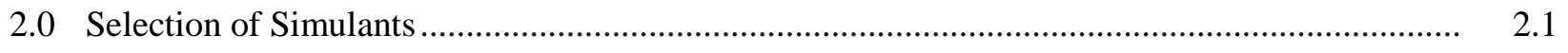

2.1 SST Blend Saltcake Simulant .................................................................................. 2.1

2.2 Simulants Based on System Plan 6 HTWOS Modeling.................................................... 2.2

2.3 Spike Levels for Constituents of Concern..................................................................... 2.7

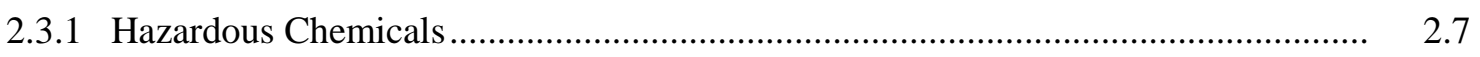

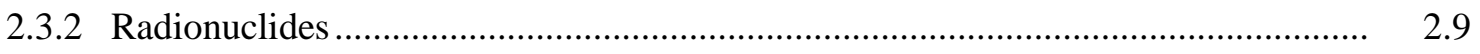

3.0 Simulant Preparation ...............................................................................................

3.1 Simulant Preparation Procedure ............................................................................. $\quad 3.1$

3.2 SST Blend Saltcake Simulant Results....................................................................... 3.1

3.3 Overall Average Simulant Results ............................................................................. 3.4

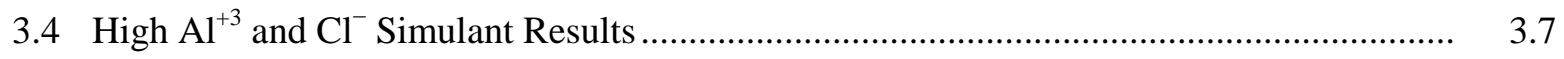

3.5 High $\mathrm{SO}_{4}{ }^{-2}$ Simulant Results................................................................................... 3.11

3.6 Final Simulant Analytical Results....................................................................... 3.14

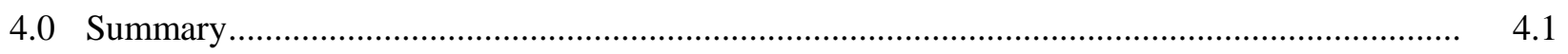

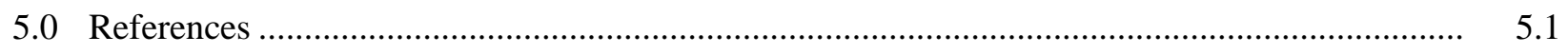

Appendix - Summary of SRNL Simulant Development ............................................................. A.1

\section{Figures}

2.1 Aluminum and Chloride Concentrations from HTWOS Flowsheet Simulation........................ 2.. 2.4

2.2 Sulfate, Phosphate, and Fluoride Concentrations from HTWOS Flowsheet Simulations .......... 2.6

3.1 5 M Na SST Blend Saltcake Simulant after Heating and Cooling.......................................... 3.2

3.2 7.8 M Na SST Blend Saltcake Simulant after Heating and Cooling........................................ 3.3

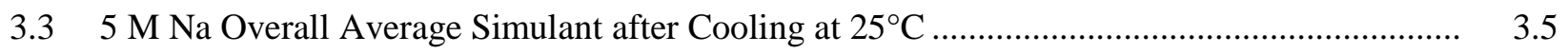

3.4 5 M Na New Composition Overall Average Simulant after Heating ...................................... 3.6

$3.55 \mathrm{M}$ Na High-Al Simulant before Heating ........................................................................... 3.8

3.6 5 M Na High-Al Simulant after Heating and before Cooling ............................................... 3.8

3.7 7.8 M Na High-Al Simulant before Heating ..................................................................... 3.9

3.8 7.8 M Na High-Al Simulant after Heating and Cooling ...................................................... 3.10

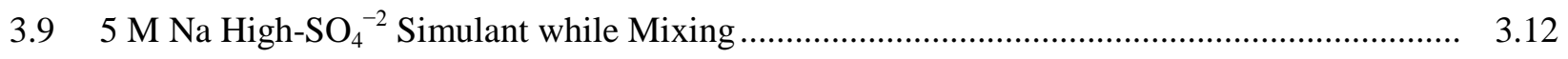

$3.105 \mathrm{M} \mathrm{Na}$ High-SO ${ }_{4}^{-2}$ Simulant after Heating..................................................................... 3.12 


\section{Tables}

2.1 Nonradioactive Dissolved Saltcake Solution Simulant Composition ....................................... 2.1

2.2 LAW Simulants Based on HTWOS Modeling ................................................................... 2.5

2.3 Spike Levels for Hazardous Constituents and Radionuclides for HTWOS Simulants ............... 2.7

2.4 Total Analysis for LAW Feed at 5 M Sodium Concentration ................................................ 2.8

2.5 Total Analysis for LAW Feed at 7.8 M Sodium Concentration ............................................. 2.8

3.1 Analytical Results of Initial 1 L Simulant Solution Composition ........................................... 3.2

3.2 Recipe for SST Blend Saltcake Simulant Based on 1 L ........................................................ 3.4

3.3 Recipe for Overall Average Simulant Based on 1 L ..........................................................

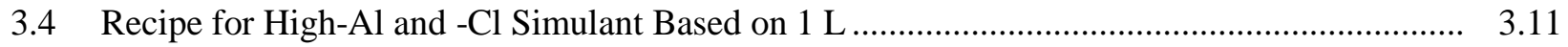

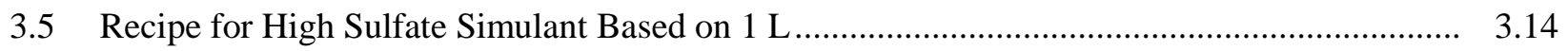

3.6 Analytical Results for 5 M Na SST Blend Saltcake Simulant Compositions ........................... 3.16

3.7 Analytical Results for 7.8 M Na SST Blend Saltcake Simulant Compositions ........................ 3.17

3.8 Analytical Results for $5 \mathrm{M}$ Na Overall Average Simulant Compositions ................................ 3.18

3.9 Analytical Results for 7.8 M Na Overall Average Simulant Compositions ............................ 3.19

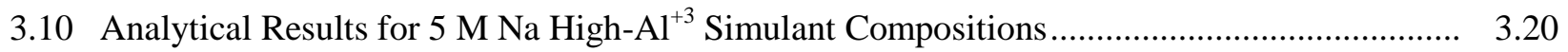

3.11 Analytical Results for 7.8 M Na High- $\mathrm{Al}^{+3}$ Simulant Compositions ....................................... 3.21

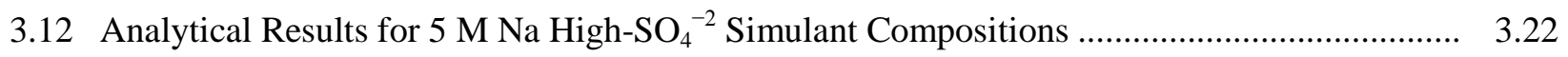

3.13 Analytical Results for 7.8 M Na High-SO ${ }_{4}^{-2}$ Simulant Compositions ................................... 3.23

4.1 Final LAW Simulants for Cast Stone Screening Tests ............................................................. 4.2

4.2 Final Spike Levels for Hazardous Constituents and Radionuclides for Cast Stone

Screening Test Simulants.......................................................................................... 4.2 


\subsection{Introduction}

More than 56 million gallons of radioactive and hazardous waste are stored in 177 underground storage tanks at the U.S. Department of Energy's (DOE's) Hanford Site in southeastern Washington State. The Hanford Tank Waste Treatment and Immobilization Plant (WTP) is being constructed to treat the wastes and immobilize them in a glass waste form. The WTP includes a pretreatment facility to separate the wastes into a small volume of high-level waste (HLW) containing most of the radioactivity and a larger volume of low-activity waste (LAW) containing most of the nonradioactive chemicals. The HLW will be converted to glass in the HLW vitrification facility for ultimate disposal at an offsite federal repository. At least a portion ( 35\%) of the LAW will be converted to glass in the LAW vitrification facility and will be disposed of onsite at the Integrated Disposal Facility (IDF). The pretreatment and HLW vitrification facilities will have the capacity to treat and immobilize the wastes destined for each facility. However, a second facility will be needed for the expected volume of additional LAW requiring immobilization.

A cementitious waste form known as Cast Stone is being considered to provide the required additional LAW immobilization capacity. The Cast Stone waste form must be acceptable for disposal in the IDF. The Cast Stone waste form and immobilization process must be tested to demonstrate that the final Cast Stone waste form can comply with waste acceptance criteria for the IDF disposal facility and that the immobilization processes can be controlled to consistently provide an acceptable waste form product. Further, the waste form must be tested to provide the technical basis for understanding the long-term performance of the waste form in the IDF disposal environment. These waste form performance data are needed to support risk assessment and performance assessment (PA) analyses of the long-term environmental impact of the waste disposal in the IDF.

A testing program was developed in fiscal year (FY) 2012 describing in some detail the work needed to develop and qualify Cast Stone as a waste form for the solidification of Hanford LAW (Westsik et al. 2012). Included within Westsik et al. (2012) is a section on the near-term needs to address Tri-Party Agreement Milestone M-062-40ZZ. The objectives of the testing program to be conducted in FY 2013 and FY 2014 are to:

- Determine an acceptable formulation for the LAW Cast Stone waste form.

- Evaluate sources of dry materials for preparing the LAW Cast Stone.

- Demonstrate the robustness of the Cast Stone waste form for a range of LAW compositions.

- Demonstrate the robustness of the formulation for variability in the Cast Stone process.

- Provide Cast Stone contaminant release data for PA and risk assessment evaluations.

The first step in determining an acceptable formulation for the LAW Cast Stone waste form is to conduct screening tests to examine expected ranges in pretreated LAW composition, waste stream concentrations, dry-materials sources, and mix ratios of waste feed to dry blend. A statistically designed test matrix will be used to evaluate the effects of these key parameters on the properties of the Cast Stone as it is initially prepared and after curing.

The second phase of testing will focus on selection of a baseline Cast Stone formulation for LAW and demonstrating that Cast Stone can meet expected waste form requirements for disposal in the IDF. It is expected that this testing will use the results of the screening tests to define a smaller suite of tests to 
refine the composition of the baseline Cast Stone formulation (e.g. waste concentration, water to dry mix ratio, waste loading).

Preparation and testing of LAW Cast Stone containing actual radioactive wastes will be conducted to provide confirmation that the results observed with chemical simulants in the screening, waste loading, and waste form qualification testing are representative of what is expected with actual wastes.

After selection of a baseline Cast Stone formulation for LAW, an engineering-scale demonstration of the Cast Stone process and containerized waste form may be conducted in FY 2014 depending on the availability of funding.

To support the screening testing, chemical simulants of the LAW wastes to be solidified in the Cast Stone are needed. This letter report summarizes the selection and development of the chemical simulants to be used in at least the initial screening tests described above.

\subsection{Tank Waste Processing}

The Cast Stone process is being evaluated to treat and immobilize LAW separated from the radioactive waste currently stored in the underground storage tanks at Hanford. The LAW fraction of the waste is characterized as a large-volume, low-radioactivity liquid process stream stripped of most of the solids, transuranic elements and long-lived radionuclides. The LAW is derived from the aqueous solutions in the tanks and dissolved saltcake. The composition of the LAW will vary from tank to tank because of the variability in types and sources of wastes stored in the individual tanks and the processes used to separate the wastes into HLW and LAW fractions.

The baseline source of the LAW wastes to be treated and immobilized through the Cast Stone process is the separations processes within the WTP pretreatment facility. The liquid wastes from the tanks will pass through ultrafilters in the pretreatment facility to remove solids, which include insoluble radioisotopes, primarily strontium and transuranics (TRU). For some tank wastes, additional processing as part of the ultrafiltration process will remove aluminum and/or chromium from the solids destined for $\mathrm{HLW}$, and the $\mathrm{Al}$ and $\mathrm{Cr}$ will be added to the LAW stream. Some tanks contain organic complexants that keep strontium and transuranic elements in the aqueous phase. The treatment of these wastes will include a precipitation step to remove the Sr and TRU from solution before the ultrafiltration step. For LAW wastes with higher concentrations of organic complexants, it may be decided to send these wastes to LAW vitrification because of the organic content.

The liquid filtrate from the ultrafilters will then pass through ion exchange columns to remove cesium. The effluent from the ion exchange columns will then be concentrated in an evaporator to a specified sodium concentration depending on the waste composition. The concentrated solution from the evaporator will comprise the feed to the immobilization process. The waste feed will principally be alkaline solutions of sodium with nitrate, nitrite, hydroxide, carbonate, and a spectrum of radioactive fission products. Minor components can include aluminum, potassium and silicon along with anions such as chloride, fluoride, phosphate, and sulfate. In addition to chromium, the LAW is expected to contain other Resource Conservation and Recovery Act (RCRA 1976) metals (As, Ba, Cd, Cr, Pb, Hg, Se, and $\mathrm{Ag}$ ) and underlying hazardous constituents ( $\mathrm{Sb}, \mathrm{Be}, \mathrm{Ni}$, and $\mathrm{Tl}$ ), which are important with respect to land disposal restrictions. 
To supplement WTP capacity, in-tank and at-tank separations are being considered to provide LAW feed directly to the supplemental immobilization process without processing through the WTP pretreatment facility. These near-tank processes would include a filtration step via a cross-flow filter or a rotary microfilter to remove the solids and insoluble radionuclides. Cesium and possibly some technetium would be removed through ion exchange. The separated solids and cesium would be returned to the double-shell tank (DST) system for eventual treatment and immobilization as HLW. Various disposition pathways are being considered for the separated Tc, including immobilization as HLW. The liquid effluent from these separation processes would become the feed to the LAW Cast Stone immobilization process.

Some tank wastes may be acceptable for direct Cast Stone processing without additional separations. An example of this is the low-curie salt solutions generated during the later stages of washing/dissolving saltcake from the tanks. Experience has shown that the cesium is removed in the earlier stages of saltcake dissolution such that the saltcake dissolved later is relatively free of ${ }^{137} \mathrm{Cs}$ and could be immobilized without further processing. Other tank wastes have already had soluble liquids removed or have low curie content to begin with and could be processed with minimal or no pretreatment.

Therefore, the composition of LAW to be processed as Cast Stone could vary greatly, requiring testing to look at several compositions of feed. Based on current waste flow sheet predictions, four different chemical simulant compositions were selected for the Cast Stone screening tests to assess a range of different waste compositions that may be sent to the LAW Cast Stone immobilization process. 



\subsection{Selection of Simulants}

For the initial screening tests of the Cast Stone formulation for LAW, four chemical simulants were selected to represent a range of possible LAW compositions to be solidified in the Cast Stone waste form. Included are a saltcake simulant used in previous testing of LAW immobilization technologies and three chemical simulants based on the Hanford Tank Waste Operations Simulator (HTWOS) flowsheet modeling of the LAW feed to a supplemental immobilization facility.

\subsection{SST Blend Saltcake Simulant}

Saltcake is a predominant form of wastes in a large fraction of the single-shell tanks (SSTs) at Hanford. These wastes can be readily dissolved, stripped of cesium, and converted to glass or Cast Stone waste forms for disposal. To support an evaluation of supplemental treatment alternatives for immobilizing this type of LAW, a saltcake simulant waste was developed based on a blend of real waste samples from single-shell tanks S-101, S-110, S-111, U-106, and U-109 (Rassat et al. 2003). Table 2.1 shows the nominal saltcake simulant composition. A recipe for preparing the simulant is provided by Rassat et al. (2003). This SST-blend saltcake simulant has been used in previous Cast Stone testing with Hanford LAW simulants. The composition matches the average composition of saltcake from 68 Hanford SSTs representing 85 percent of the total saltcake inventory in all Hanford SSTs and DSTs at that time (Gasper et. al., 2002).

Table 2.1. Nonradioactive Dissolved Saltcake Solution Simulant Composition (Derived from Table 3.2, Rassat et al. 2003)

\begin{tabular}{cl}
\hline Waste Constituent & $\begin{array}{c}\text { Concentration } \\
\text { (M) }\end{array}$ \\
\hline $\mathrm{Al}$ & 0.0637 \\
$\mathrm{Cs}$ & $5.1 \times 10^{-8}$ \\
$\mathrm{Cr}$ & 0.0104 \\
$\mathrm{~K}$ & 0.0124 \\
$\mathrm{Na}$ & 5.00 \\
$\mathrm{Cl}$ & 0.0438 \\
$\mathrm{CO}_{3}$ & 0.475 \\
$\mathrm{~F}$ & 0.0316 \\
$\mathrm{NO}_{2}$ & 0.424 \\
$\mathrm{NO}_{3}$ & 2.51 \\
$\mathrm{PO}_{4}$ & 0.0492 \\
$\mathrm{SO}_{4}$ & 0.0900 \\
$\mathrm{C}_{2} \mathrm{O}_{4}$ (oxalate) & 0.0118 \\
$\mathrm{TOC}$ Total & 0.263 \\
OH Total $_{\text {Other } \mathrm{TOC}^{(\text {a) }}(\text { as carbon, from acetate })}$ & 0.287 \\
Free OH & 0.740 \\
\hline
\end{tabular}

(a) TOC = total organic carbon 


\subsection{Simulants Based on System Plan 6 HTWOS Modeling}

Three additional chemical simulants were developed to represent the range of LAW tank wastes that may be immobilized in a Cast Stone waste form. The chemical simulants were developed based on runs of the HTWOS model to support the River Protection Project System Plan, Revision 6 (Certa et al. 2011, Crawford et al. 2012a). As one of the outputs, the HTWOS model provides the feed vector to a supplemental immobilization facility over the course of the tank waste cleanup mission. The feed vector is in the form of weekly tallies of feed delivered to the Supplemental LAW (S/LAW) Immobilization Facility.

The first chemical simulant is an overall average of the 1046 weekly compositions of modeled waste feed over a twenty-year mission. This is a good central waste composition for the initial Cast Stone studies.

The second chemical simulant is a high-Al, high-Cl simulant corresponding to week 235 in the HTWOS flowsheet simulation. It corresponds to the maximum Al concentration normalized to sodium. $\mathrm{Cl}$ is near its maximum as well. Unlike $\mathrm{SO}_{4}^{-2}$ and $\mathrm{F}^{-}$, $\mathrm{Al}$ doesn't have a single spike at a high concentration but a broad region between 0.08 and 0.1 mole/mole Na. Figure 2.1 shows the concentrations of $\mathrm{Al}\left(\mathrm{as} \mathrm{Al}(\mathrm{OH})_{4}{ }^{-}\right.$) and $\mathrm{Cl}^{-}$for the 1046 weeks modeled in the HTWOS simulation. The point at week 235 is circled in green.

The third chemical simulant is characterized by phosphate near its maximum and sulfate and fluoride at relatively high concentrations. This corresponds to week 672 in the HTWOS flowsheet simulation. Figure 2.2 shows the concentrations of $\mathrm{SO}_{4}{ }^{-2}, \mathrm{PO}_{4}{ }^{-3}$, and $\mathrm{F}^{-}$for this selected week. This week was selected over the later times near the end of mission that are predicted to have higher spikes in sulfate and fluoride concentrations because it is not immediately clear what the sources of these late spikes are, and they are not representative of most of the WTP mission duration. Also, HTWOS does not use thermodynamic models to predict solubilities. For example, as will be discussed later, it is unlikely that such high levels of phosphate and fluoride could be maintained in solution at the high $\mathrm{pH}$ and ionic strength of these waste compositions.

Table 2.2 shows the three additional chemical simulants as well as the SST blend saltcake simulant described in Section 2.1 above. For comparison purposes, the simulants have been normalized to onemolar sodium and are expressed as moles per mole of sodium. These simulants were selected to represent a range of waste feed compositions for a low temperature Cast Stone immobilization process but were initially based on a single HTWOS simulation that did not include a separate at-tank or near-tank supplemental pretreatment process.

As a verification step, the component ranges shown in Figures 2.1 and 2.2 and the compositions in Table 2.2 were compared to HTWOS outputs from a simulation that specifically modeled Supplemental LAW Immobilization as a low temperature immobilization process. That process would receive feed from both the WTP Pretreatment Facility and a supplemental pretreatment process on an as needed basis (Crawford et al. 2012b, Feero 2012). The results of this comparison revealed the following:

- The overall average LAW composition over the entire waste treatment mission duration was essentially unchanged. 
- The composition of LAW feed from the WTP Pretreatment Facility did not change significantly in terms of ranges of concentrations (mole ratios to $\mathrm{Na}$ ) of constituents of interest.

- The compositions of waste feeds from supplemental pretreatment were much less variable from week to week and in all cases the ranges were bounded by the feed compositions from WTP Pretreatment.

The values for the HTWOS simulants in Table 2.2 are before charge balancing. The three chemical simulants identified from the HTWOS modeling were charge balanced by adjusting all of the anions so that they remained in the same ratios. For the final simulant recipes shown in Table 4.1 below, the charge balance was performed by summing the charges of the anions $\left(\mathrm{Al}(\mathrm{OH})_{4}^{-}(1 \times), \mathrm{Cl}^{-}(1 \times), \mathrm{CO}_{3}^{-2}(2 \times)\right.$, $\mathrm{F}^{-}(1 \times), \mathrm{NO}_{2}{ }^{-}(1 \times), \mathrm{NO}_{3}{ }^{-}(1 \times), \mathrm{PO}_{4}{ }^{3-}(3 \times), \mathrm{SO}_{4}{ }^{2-}(2 \times), \mathrm{C}_{2} \mathrm{H}_{3} \mathrm{O}_{2}{ }^{-}(1 \times)$, and free $\left.\mathrm{OH}^{-}(1 \times)\right)$ and then subtracting the charge associated with the cations $\mathrm{K}^{+}(1 \times)$ (if present) and $\mathrm{Na}^{+}(1 \times)$. The total moles of anions were set to equal the calculation of the total moles of cations $(\mathrm{Na}+\mathrm{K})$ and the individual anion molarities were adjusted in proportion to total moles of anions until they balanced. 

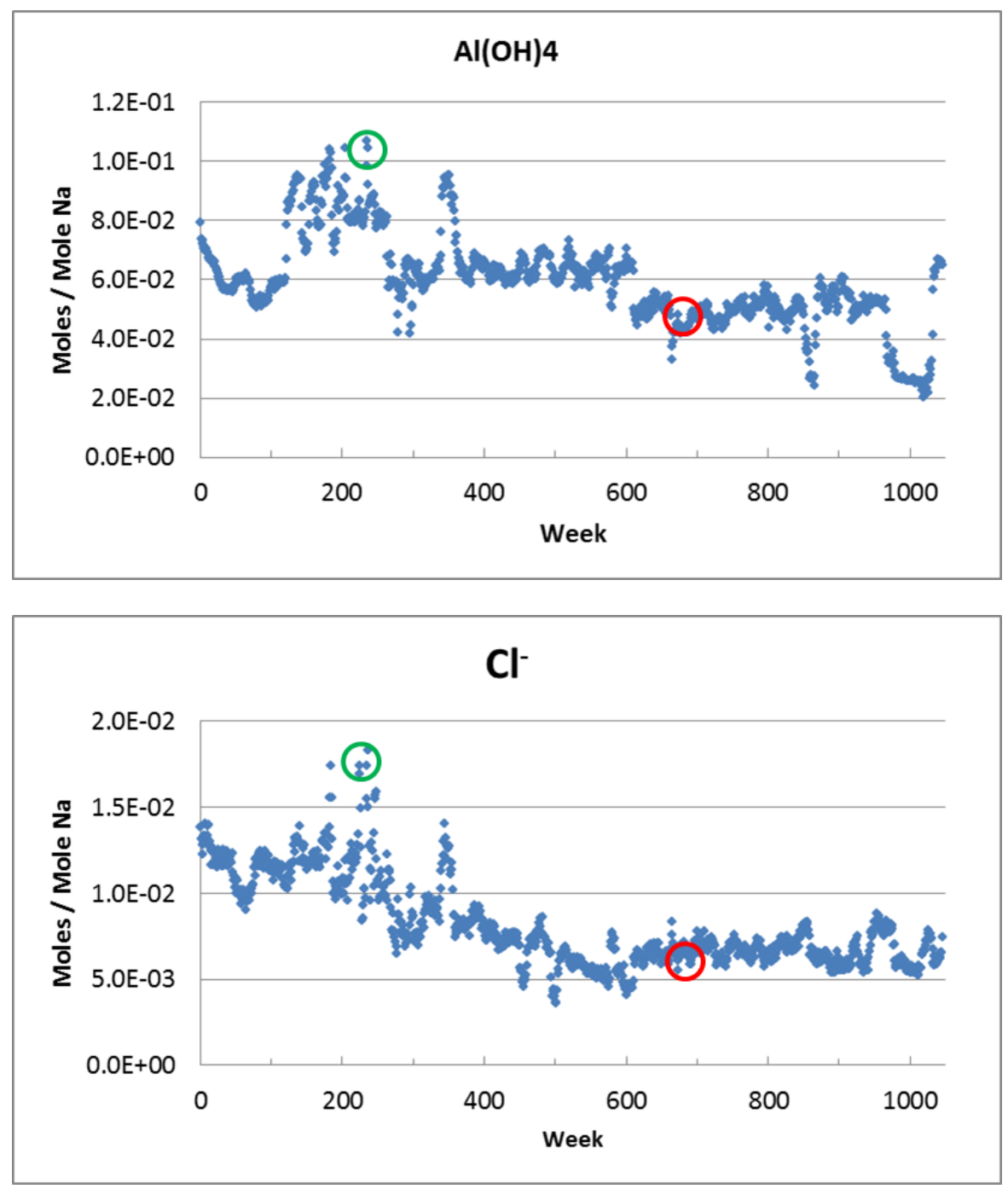

Figure 2.1. Aluminum and Chloride Concentrations from HTWOS Flowsheet Simulation. Week 235 in green circle, week 672 in red circle. 
Table 2.2. LAW Simulants Based on HTWOS Modeling

\begin{tabular}{|c|c|c|c|c|}
\hline & $\begin{array}{l}\text { SST Blend } \\
\text { Saltcake }\end{array}$ & $\begin{array}{c}\text { HTWOS } \\
\text { Overall } \\
\text { Average }\end{array}$ & $\begin{array}{c}\text { HTWOS } \\
\text { High } \\
\text { Al, Cl }\end{array}$ & $\begin{array}{c}\text { HTWOS } \\
\text { High } \\
\mathrm{PO}_{4}, \mathrm{SO}_{4}, \mathrm{~F}\end{array}$ \\
\hline Waste Constituent & \multicolumn{4}{|c|}{ Concentration (moles / mole Na) ${ }^{(\mathrm{a})}$} \\
\hline $\mathrm{Na}$ & 1.000 & 1.000 & 1.000 & 1.000 \\
\hline $\mathrm{K}$ & 0.002 & 0.007 & 0.028 & 0.002 \\
\hline $\mathrm{Al}$ & 0.013 & 0.059 & 0.107 & 0.045 \\
\hline $\mathrm{Cl}$ & 0.009 & 0.008 & 0.017 & 0.007 \\
\hline $\mathrm{F}$ & 0.006 & 0.028 & 0.010 & 0.040 \\
\hline $\mathrm{SO}_{4}$ & 0.018 & 0.017 & 0.004 & 0.029 \\
\hline $\mathrm{PO}_{4}$ & 0.010 & 0.013 & 0.005 & 0.032 \\
\hline $\mathrm{NO}_{2}$ & 0.085 & 0.109 & 0.185 & 0.094 \\
\hline $\mathrm{NO}_{3}$ & 0.502 & 0.313 & 0.274 & 0.351 \\
\hline $\mathrm{CO}_{3}$ & 0.095 & 0.053 & 0.038 & 0.033 \\
\hline TOC Total & 0.057 & 0.015 & 0.020 & 0.007 \\
\hline Free OH & 0.097 & 0.301 & 0.280 & 0.293 \\
\hline
\end{tabular}

(a) From HTWOS output before charge balancing 

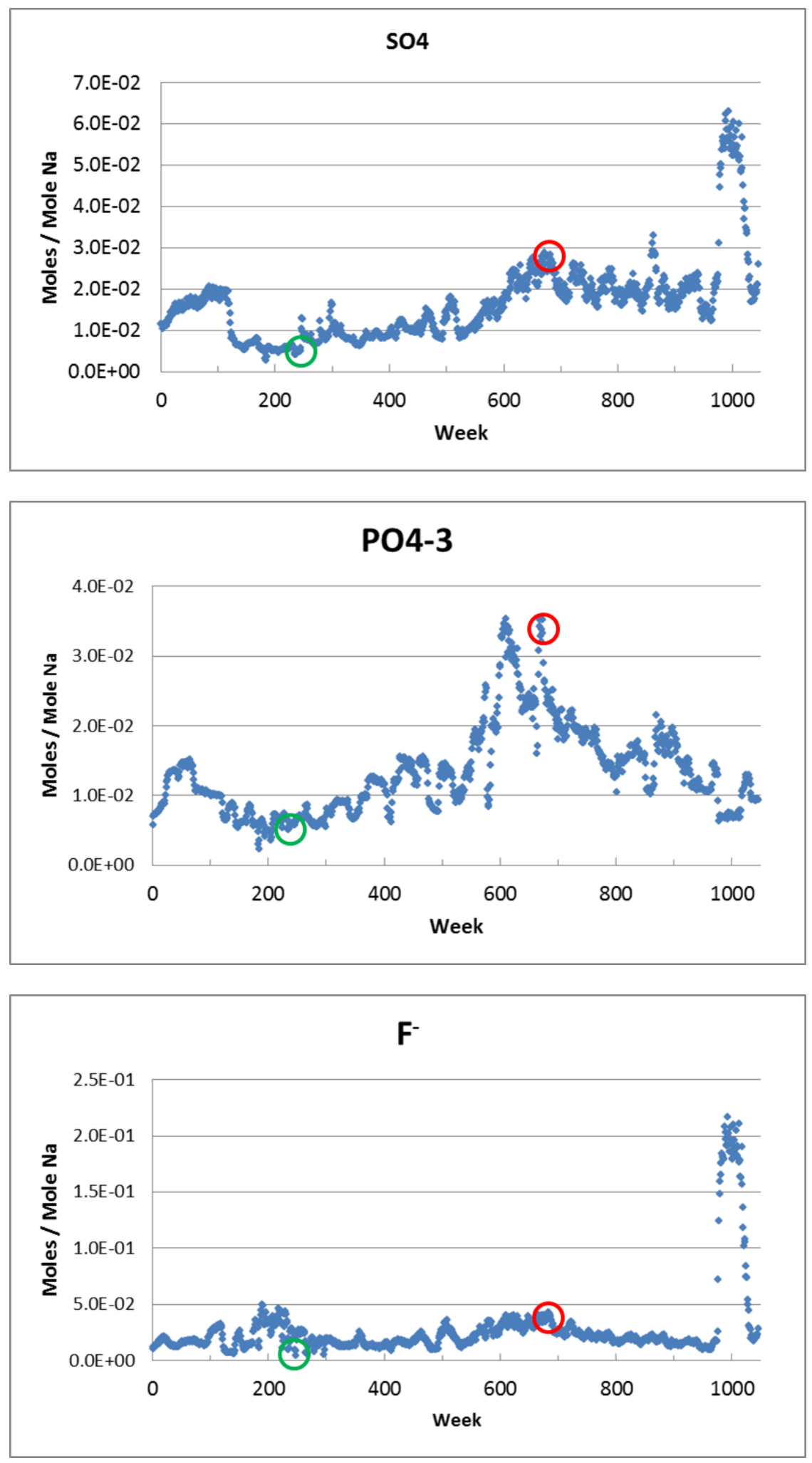

Figure 2.2. Sulfate, Phosphate, and Fluoride Concentrations from HTWOS Flowsheet Simulations. Week 672 in red circle, week 235 in green circle. 


\subsection{Spike Levels for Constituents of Concern}

In addition to the main components of the LAW, the simulants used to make Cast Stone waste forms used in contaminant release testing were spiked with hazardous chemicals and/or radionuclides of interest to determine how well the Cast Stone waste form controls the release of these constituents of concern (COCs).

\subsubsection{Hazardous Chemicals}

Some testing will require the use of spike additions of COCs to address their retention and release within the Cast Stone waste form. To address land disposal restrictions (LDRs) including performance in the Environmental Protection Agency (EPA) Method 1311, Toxicity Characteristic Leaching Procedure (EPA 1992), the chosen simulants were spiked with RCRA metals and underlying hazardous constituents. An initial RCRA spike vector was selected by taking the maximum weekly batch values from HTWOS System Plan 6 for the feed to Supplemental Low Activity Waste (S/LAW) Treatment as shown in Table 2.3.

Table 2.3. Spike Levels for Hazardous Constituents and Radionuclides for HTWOS Simulants

\begin{tabular}{cccc}
\hline Waste Constituent & $\begin{array}{c}\text { HTWOS } \\
\text { Overall } \\
\text { Average }\end{array}$ & $\begin{array}{c}\text { HTWOS } \\
\text { Maximum }\end{array}$ & $\begin{array}{c}\text { Other } \\
\text { Considerations }\end{array}$ \\
\hline RCRA Metals & moles/mole Na & moles/mole Na & moles/mole Na \\
\hline $\mathrm{As}$ & $4.24 \mathrm{E}-06$ & $4.78 \mathrm{E}-05$ & - \\
$\mathrm{Ba}$ & $5.65 \mathrm{E}-07$ & $5.21 \mathrm{E}-06$ & - \\
$\mathrm{Cd}$ & $2.78 \mathrm{E}-06$ & $3.19 \mathrm{E}-05$ & - \\
$\mathrm{Cr}$ & $2.42 \mathrm{E}-03$ & $9.99 \mathrm{E}-03$ & $4.30 \mathrm{E}-03^{(\mathrm{a})}$ \\
$\mathrm{Pb}$ & $1.16 \mathrm{E}-05$ & $5.13 \mathrm{E}-05$ & - \\
$\mathrm{Hg}$ & $1.37 \mathrm{E}-06$ & $6.97 \mathrm{E}-06$ & - \\
$\mathrm{Se}$ & $1.95 \mathrm{E}-05$ & $4.63 \mathrm{E}-05$ & - \\
$\mathrm{Ag}$ & $7.49 \mathrm{E}-07$ & $5.40 \mathrm{E}-06$ & - \\
\hline & Underlying Hazardous Constituents & & - \\
\hline $\mathrm{Sb}$ & $2.82 \mathrm{E}-06$ & $1.97 \mathrm{E}-05$ & - \\
\hline $\mathrm{Be}$ & $1.58 \mathrm{E}-06$ & $2.06 \mathrm{E}-05$ & - \\
$\mathrm{Ni}$ & $6.41 \mathrm{E}-05$ & $6.61 \mathrm{E}-04$ & - \\
$\mathrm{Tl}$ & $1.42 \mathrm{E}-05$ & $1.37 \mathrm{E}-05$ & $\mathrm{Ci} / \mathrm{mole} \mathrm{Na}$ \\
\hline $\mathrm{Radionuclides}$ & $\mathrm{Ci} / \mathrm{mole} \mathrm{Na}$ & $\mathrm{Ci} / \mathrm{mole} \mathrm{Na}$ & - \\
\hline${ }^{99} \mathrm{Tc}$ & $1.13 \mathrm{E}-05$ & $4.13 \mathrm{E}-05$ & $3.54 \mathrm{E}-06^{(\mathrm{b})}$ \\
\hline${ }^{129} \mathrm{I}$ & $1.44 \mathrm{E}-08$ & $8.01 \mathrm{E}-08$ & - \\
\hline $\mathrm{U}$ & $1.59 \mathrm{E}-08$ & $5.63 \mathrm{E}-08$ & -08 \\
\hline
\end{tabular}

(a) Cr concentration adjusted based on review of best basis inventory and previous simulant work.

(b) I concentration increased to address possible detection limits issues in waste form leach tests.

The list of RCRA metals to include in the simulants was reduced using Total Constituent Analysis as allowed in Section 1.2 of the Toxicity Characteristic Leaching Procedure (EPA 1992). Conceptually, this analysis shows what the TCLP leachate concentrations would be if $100 \%$ of each COC were released from the waste form during the leaching procedure. This initial screen showed As, Ba, Se, Ag, Sb, Be, and Ni to be below Universal Treatment Standards (UTS) as shown in Table 2.4 and Table 2.5 in standard 
type. The elements shown in bold type in Table 2.4 and Table 2.5 were found to be above the UTS after an initial screening. None of the COCs that fall below UTS by total analysis were added to the simulants in the initial phase of the screening matrix with the exception of nickel. Nickel was included because it contributes a significant mass to the RCRA vector.

Table 2.4. Total Analysis for LAW Feed at 5 M Sodium Concentration ${ }^{(a)}$

\begin{tabular}{|c|c|c|c|c|c|c|c|}
\hline RCRA Spike & MW (g) & M/M Na & Mole/L & $\begin{array}{c}\text { Concentration in } \\
\text { LAW Feed } \\
(\mathrm{mg} / \mathrm{L})\end{array}$ & $\begin{array}{c}\text { Concentration } \\
\text { in Cast Stone } \\
(\mathrm{mg} / \mathrm{Kg})\end{array}$ & $\begin{array}{c}20 x \\
\text { Dilution }\end{array}$ & $\begin{array}{l}\text { UTS, } \\
\text { mg/l }\end{array}$ \\
\hline As & 74.922 & $4.78 \mathrm{E}-05$ & $2.39 \mathrm{E}-04$ & 17.91 & 5.93 & 0.297 & 5 \\
\hline $\mathrm{Ba}$ & 137.34 & $5.31 \mathrm{E}-06$ & $2.66 \mathrm{E}-05$ & 3.65 & 1.21 & 0.060 & 21 \\
\hline Cd & 112.4 & $3.19 E-05$ & $1.60 \mathrm{E}-04$ & 17.93 & 5.94 & 0.297 & 0.11 \\
\hline $\mathbf{C r}$ & 51.996 & $4.30 \mathrm{E}-03$ & $2.15 E-02$ & 1117.91 & 370.49 & 18.525 & 0.6 \\
\hline $\mathbf{P b}$ & 207.19 & $5.13 E-05$ & $2.57 E-04$ & 53.14 & 17.61 & 0.881 & 0.75 \\
\hline Hg & 200.59 & $6.97 E-06$ & $3.49 \mathrm{E}-05$ & 6.99 & 2.32 & 0.116 & 0.025 \\
\hline Se & 78.96 & $4.63 \mathrm{E}-05$ & $2.32 \mathrm{E}-04$ & 18.28 & 6.06 & 0.303 & 5.7 \\
\hline $\mathrm{Ag}$ & 107.87 & $5.40 \mathrm{E}-06$ & $2.70 \mathrm{E}-05$ & 2.91 & 0.97 & 0.048 & 0.14 \\
\hline $\mathrm{Sb}$ & 121.75 & $1.97 \mathrm{E}-05$ & $9.85 \mathrm{E}-05$ & 11.99 & 3.97 & 0.199 & 1.15 \\
\hline $\mathrm{Be}$ & 9.0122 & $2.06 \mathrm{E}-5$ & $1.03 \mathrm{E}-4$ & 0.93 & 0.31 & 0.015 & 1.22 \\
\hline $\mathrm{Ni}$ & 58.71 & $6.61 \mathrm{E}-04$ & $3.31 \mathrm{E}-03$ & 194.04 & 64.31 & 3.215 & 11 \\
\hline Tl & 204.37 & $1.37 E-05$ & $6.85 E-05$ & 14.00 & 4.64 & 0.232 & 0.2 \\
\hline
\end{tabular}

(a) Based on $1.201 \mathrm{~kg}(0.978 \mathrm{~L})$ simulant weight and $1.75 \mathrm{~kg}$ dry material weight.

Table 2.5. Total Analysis for LAW Feed at 7.8 M Sodium Concentration ${ }^{(a)}$

\begin{tabular}{|c|c|c|c|c|c|c|c|}
\hline RCRA Spike & MW (g) & $\mathbf{M} / \mathbf{M} \mathbf{N a}$ & Mole/L & $\begin{array}{c}\text { Concentration in } \\
\text { LAW Feed } \\
\text { (mg/L) }\end{array}$ & $\begin{array}{c}\text { Concentration } \\
\text { in Cast Stone } \\
(\mathrm{mg} / \mathrm{Kg})\end{array}$ & $\begin{array}{c}20 \times \\
\text { Dilution } \\
\end{array}$ & $\begin{array}{l}\text { UTS, } \\
\text { mg/L }\end{array}$ \\
\hline As & 74.922 & $4.78 \mathrm{E}-05$ & $3.73 \mathrm{E}-04$ & 27.93 & 9.13 & 0.456 & 5 \\
\hline $\mathrm{Ba}$ & 137.34 & $5.31 \mathrm{E}-06$ & $4.14 \mathrm{E}-05$ & 5.69 & 1.86 & 0.093 & 21 \\
\hline Cd & 112.4 & $3.19 E-05$ & $2.49 E-04$ & 27.97 & 9.14 & 0.457 & 0.11 \\
\hline $\mathrm{Cr}$ & 51.996 & $4.30 \mathrm{E}-03$ & $3.35 E-02$ & 1743.95 & 569.87 & 28.493 & 0.6 \\
\hline $\mathbf{P b}$ & 207.19 & $5.13 E-05$ & $4.00 E-04$ & 82.91 & 27.09 & 1.355 & 0.75 \\
\hline Hg & 200.59 & $6.97 E-06$ & $5.44 \mathrm{E}-05$ & 10.91 & 3.56 & 0.178 & 0.025 \\
\hline Se & 78.96 & $4.63 \mathrm{E}-05$ & $3.61 \mathrm{E}-04$ & 28.52 & 9.32 & 0.466 & 5.7 \\
\hline Ag & 107.87 & $5.40 \mathrm{E}-06$ & $4.21 \mathrm{E}-05$ & 4.54 & 1.48 & 0.074 & 0.14 \\
\hline $\mathrm{Sb}$ & 121.75 & $1.97 \mathrm{E}-05$ & $1.54 \mathrm{E}-04$ & 18.71 & 6.11 & 0.306 & 1.15 \\
\hline $\mathrm{Be}$ & 9.0122 & $2.06 \mathrm{E}-5$ & $1.61 \mathrm{E}-4$ & 1.45 & 0.47 & 0.024 & 1.22 \\
\hline $\mathrm{Ni}$ & 58.71 & $6.61 \mathrm{E}-04$ & $5.16 \mathrm{E}-03$ & 302.70 & 98.91 & 4.946 & 11 \\
\hline Tl & 204.37 & $1.37 E-05$ & $1.07 E-04$ & 21.84 & 7.14 & 0.357 & 0.2 \\
\hline
\end{tabular}

(a) Based on $1.347 \mathrm{~kg}(1.012 \mathrm{~L})$ simulant weight and $1.75 \mathrm{~kg}$ dry material weight.

Mercury was excluded due to anticipated interactions with iodine. Mercury and silver can form highly insoluble compounds with iodine which would decrease the ability of iodine to leach from the waste form. Since the initial vector is using HTWOS maximum weekly values, it would be unrealistic to 
test iodine performance in the presence of these other compounds that would have the effect of improving iodine performance in both the TCLP and EPA 1315 leach testing.

Thallium was not included in this initial phase of the screening matrix because the secondary waste Cast Stone program showed satisfactory performance for thallium in leach testing. Thallium is also very close to the UTS value by total analysis $(0.36 \mathrm{mg} / \mathrm{L}$ versus $0.2 \mathrm{mg} / \mathrm{L})$ and thus would require minimal attenuation in leach testing to meet the UTS.

The HTWOS System Plan 6 predicts a maximum chromium level in the LAW supplemental feed of $1.0 \times 10^{-2} \mathrm{M} / \mathrm{M}$ Na. The average is $2.4 \times 10^{-3} \mathrm{M} / \mathrm{M}$ Na and the $95^{\text {th }}$ percentile is $4.3 \times 10^{-3} \mathrm{M} / \mathrm{M}$ Na. The 2003 Cast Stone work used the SST blend saltcake simulant with a Cr level of $2.0 \times 10^{-3} \mathrm{M} / \mathrm{M} \mathrm{Na}$ and the SST saltcake blend of real waste with a ratio of $3.7 \times 10^{-3} \mathrm{M} / \mathrm{M} \mathrm{Na}$ (Rapko et al. 2003).

Simulants used in testing Cast Stone for the secondary waste program used a Cr ratio as high as $4.2 \times 10^{-3} \mathrm{M} / \mathrm{M}$ Na (Sundaram et al. 2011).

Based upon the preceding information, a chromium spike level of $4.3 \times 10^{-3} \mathrm{M} / \mathrm{M}$ Na corresponding to the HTWOS $95^{\text {th }}$ percentile composition was selected for supplemental LAW Cast Stone waste form testing.

\subsubsection{Radionuclides}

To understand the retention and release of radionuclides of concern, spikes of ${ }^{99} \mathrm{Tc},{ }^{129} \mathrm{I}$ (substituted with non-radioactive ${ }^{127}$ I) and uranium will be added to Cast Stone batches prepared for leach testing studies. Table 2.3 shows the spike levels for these radionuclides.

One objective in selecting the iodine spike level for the Cast Stone screening test matrix was to choose a concentration that would result in detectable levels of iodine in leachates at a Leach Index of 11 from EPA Method 1315, Mass Transfer Rates of Constituents in Monolith or Compacted Granular Materials Using a Semi-Dynamic Tank Leaching Test (EPA 2009). A prospective calculation of leachate concentrations that would correspond to a leach index of 11 at an inductively coupled plasma-mass spectroscopy (ICP-MS) analytical detection level of $5 \mu \mathrm{g} / \mathrm{L}$ was performed. This yielded a recommended iodine spike level of $290 \mathrm{mg} / \mathrm{L}$ in the LAW simulants. A separate simplified calculation using equations from the American Nuclear Society (ANS) 16.1 method (ANS 2009) yielded $73 \mathrm{mg} / \mathrm{L}$ in the LAW simulant to be detectable in leachate samples from a 24 hour leach interval.

Another objective was to mimic the HTWOs predicted concentration of ${ }^{129} \mathrm{I}$ in the LAW feeds. The maximum weekly iodine mole ratio to sodium extracted from the HTWOS run supporting MMR 12-028 corresponds to an ${ }^{129} \mathrm{I}$ concentration of $0.99 \mathrm{mg} / \mathrm{L}$ for a $5 \mathrm{M}$ Na solution. This value is significantly lower than what would be needed to routinely detect iodine in the Cast Stone leachates should the leach index equal 11. For Cast Stone samples made with liquid secondary waste simulant at comparable iodine concentrations, iodine concentrations were detected in leachates at Leach Indices approaching 11 in EPA Method 1315 tests (Mattigod et al. 2011). However, these were typically detected only at the longer leach intervals.

Therefore, in order to increase the probability of being able to detect iodine in as many of the leachates as possible and at various leach intervals, Washington River Protection Solutions (WRPS) 
recommended spiking iodine in the LAW simulants at $100 \mathrm{mg} / \mathrm{L}$ for the $5 \mathrm{M}$ Na simulants and $156 \mathrm{mg} / \mathrm{L}$ for the $7.8 \mathrm{M}$ simulants. 


\subsection{Simulant Preparation}

Trial batches of each of the simulants were prepared at the one-liter size to look for chemical interactions and solids formation. Once satisfactory recipes were determined, larger, multi-liter size batches of each of the simulants were prepared for use in the Cast Stone waste form screening tests.

\subsection{Simulant Preparation Procedure}

The four chemical simulants described in Sections 2.1 and 2.2 were used in this testing. Each simulant was initially prepared in a $1 \mathrm{~L}$ volumetric flask at a $5 \mathrm{M}$ Na concentration. The order of chemical addition was determined based on chemical solubility knowledge, with the large amounts of more soluble chemicals added last. Generally, the small amounts of highly soluble chemicals were added first. Then the less soluble chemicals were added including the sulfate, fluoride and aluminum salts. Then the sodium hydroxide was added, followed by the phosphate, carbonate, nitrite and nitrate salts. Adding the large mass of nitrate at this point is not affected by the presence of the other chemicals because of its high solubility. The carbonate and nitrite salts were added after the sodium hydroxide and more soluble salts to promote their remaining in solution. For the HTWOS simulants, acetate was selected as the source of total organic carbon because of its higher solubility compared with oxalate. Dissolved silicon would have been a minor component in some of the simulants but was excluded because it would be insignificant compared to the large amount of silica present in the dry materials.

Each simulant was stirred and heated to between $70^{\circ} \mathrm{C}$ and $90^{\circ} \mathrm{C}$ and held at temperature for about 2 hours to help all of the constituents dissolve. After heating, each simulant was slowly cooled to $\sim 25^{\circ} \mathrm{C}$ in an environmentally controlled chamber. After cooling and holding for 24-48 hours, each simulant was centrifuged to remove any solids that formed. After solids removal, each simulant was then analyzed to determine the remaining solution composition as shown in Table 3.1.

Based on the analyzed composition, another batch of $5 \mathrm{M}$ Na simulant was prepared to confirm that this composition could remain in solution after heating and cooling if needed. If the analyzed $5 \mathrm{M} \mathrm{Na}$ simulant composition remained in solution, a batch of 7.8 $\mathrm{M}$ Na simulant was prepared based on the soluble $5 \mathrm{M}$ Na simulant composition. The $7.8 \mathrm{M}$ Na simulant was prepared in the same way as the $5 \mathrm{M}$ Na simulant.

Once a composition for each simulant and each Na molarity had been established (see Tables 4.1 and 4.2), a larger amount of each simulant was prepared for use in the preparation of the Cast Stone waste form samples for screening tests.

\subsection{SST Blend Saltcake Simulant Results}

When the initial $5 \mathrm{M}$ Na simulant was prepared in a 1-L volumetric flask, not many solids formed. The simulant was slightly cloudy and a few wispy white solids were present on the bottom of the flask. The solids easily re-suspended in the simulant solution with stirring. Each chemical added went into solution well. The simulant was then heated to $71^{\circ} \mathrm{C}$ for about 100 minutes and the simulant cleared completely. It was then placed in a temperature controlled chamber at $25^{\circ} \mathrm{C}$ to cool. After cooling and being held at $25^{\circ} \mathrm{C}$, the amount of solids was measured and found to be about $0.051 \mathrm{~g}$ in the liter of 
solution, which easily met the target of less than $0.1 \mathrm{wt} \%$ solids. The simulant was still essentially clear as shown in Figure 3.1. The yellow color is from chromium in the simulant recipe. It was decided that this composition was adequate to proceed with testing.

Table 3.1. Analytical Results of Initial 1 L Simulant Solution Composition

\begin{tabular}{|c|c|c|c|c|}
\hline Element & $\begin{array}{c}\text { SST Blend } 5 \text { M Na } \\
(\mathrm{g} / \mathrm{L})\end{array}$ & $\begin{array}{c}\text { Overall Avg } 5 \text { M Na } \\
(g / L)\end{array}$ & $\begin{array}{c}\text { High } \mathrm{Al}^{-} 5 \text { M Na } \\
(\mathrm{g} / \mathrm{L})\end{array}$ & $\begin{array}{c}\text { High } \mathrm{SO}_{4}^{-2} 5 \mathrm{M} \mathrm{Na} \\
(\mathrm{g} / \mathrm{L})\end{array}$ \\
\hline$\overline{\mathrm{Al} \text { (measured) }}$ & 1.70 & 7.92 & 12.6 & 3.03 \\
\hline Al (expected) & 1.72 & 8.09 & 15.0 & 5.80 \\
\hline Cr (measured) & 0.52 & Not present & Not present & Not present \\
\hline Cr (expected) & 0.54 & Not present & Not present & Not present \\
\hline K (measured) & 0.49 & 1.36 & 4.87 & Not present \\
\hline K (expected) & 0.48 & 1.37 & 5.67 & Not present \\
\hline Na (measured) & 112 & 111 & 112 & 95.1 \\
\hline Na (expected) & 115 & 115 & 115 & 115 \\
\hline P (measured) & 1.47 & 0.53 & 0.70 & 1.01 \\
\hline P (expected) & 1.52 & 1.99 & 7.12 & 4.54 \\
\hline $\mathrm{S}$ (measured) & 2.93 & 2.84 & 0.67 & 2.96 \\
\hline S (expected) & 2.89 & 2.70 & 5.90 & 4.25 \\
\hline
\end{tabular}

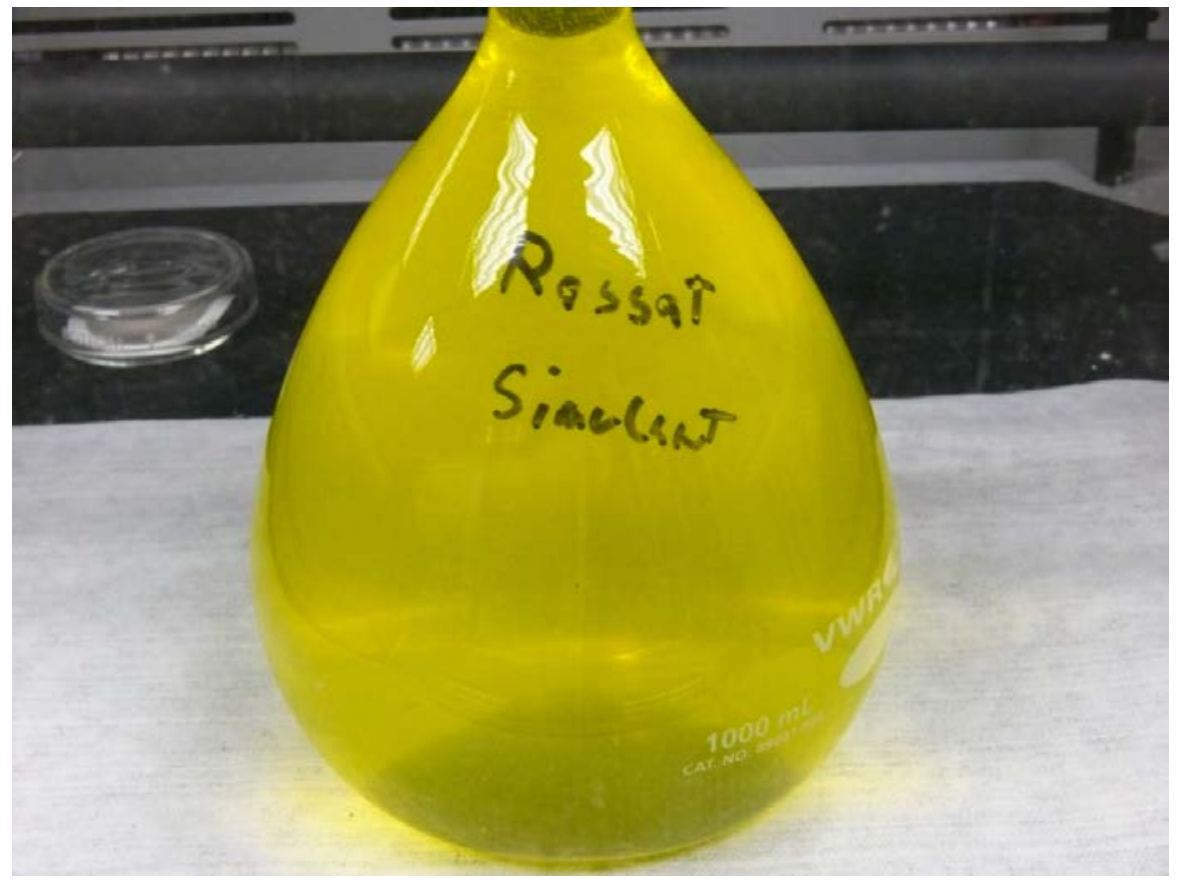

Figure 3.1. $5 \mathrm{M}$ Na SST Blend Saltcake Simulant after Heating and Cooling

A 7.8 M Na SST blend simulant was made, using the same recipe adjusted for the change in $\mathrm{Na}$ concentration, in a 1-L volumetric flask. With this simulant there were solids present after mixing and each chemical was not going into solution well after the hydroxide was added. The simulant was heated 
to $84^{\circ} \mathrm{C}$ and held for about 140 minutes and the simulant never cleared. It was then placed in a controlled temperature chamber at $25^{\circ} \mathrm{C}$ to cool. After cooling and being held at $25^{\circ} \mathrm{C}$, significant solids were present on the bottom of the flask as shown in Figure 3.2. After removal and drying, it was determined to be $18 \mathrm{~g}$ of solids.

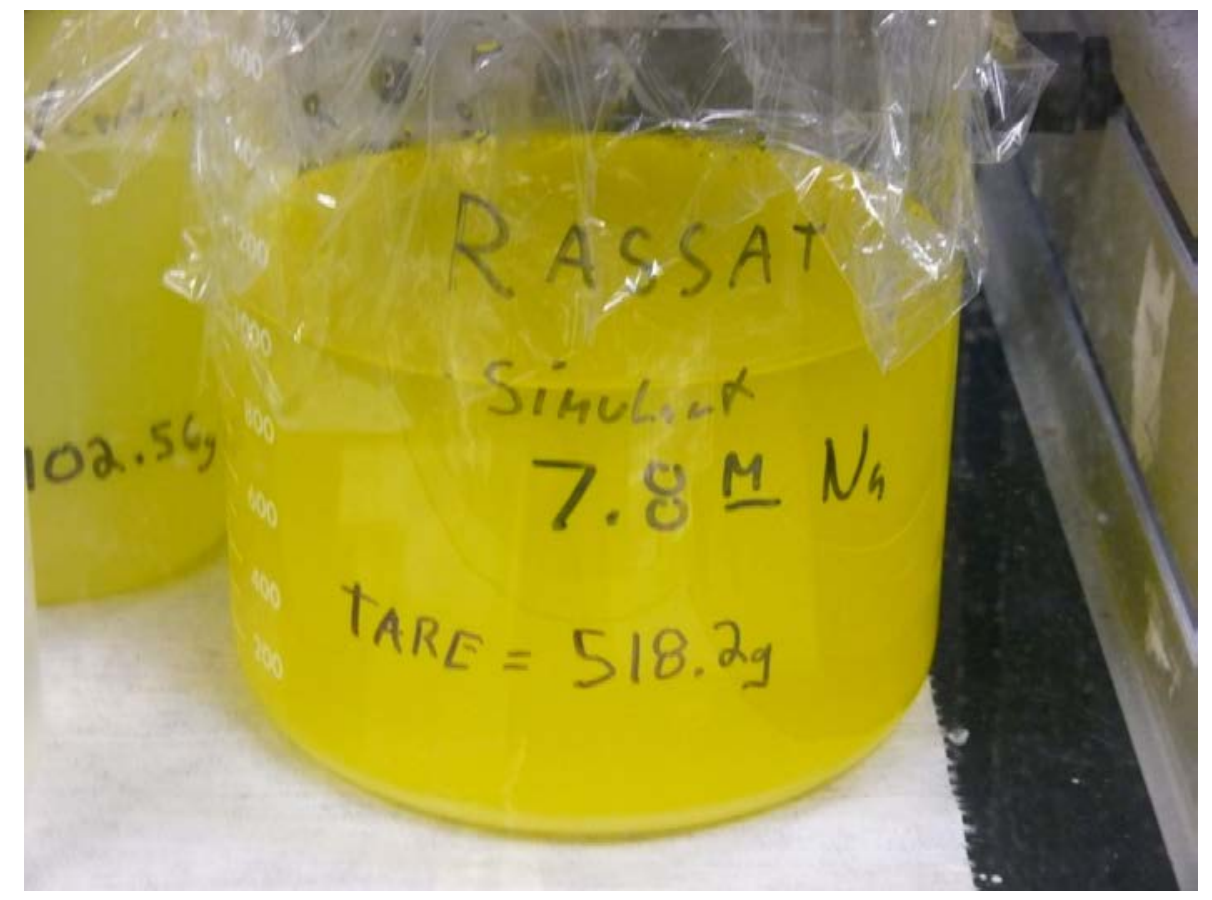

Figure 3.2. 7.8 M Na SST Blend Saltcake Simulant after Heating and Cooling

Based on these results, it was decided to proceed with the large batch simulant needed for the Cast Stone preparation. Eight-liter batches of both the $5 \mathrm{M} \mathrm{Na}$ and 7.8 M Na SST blend compositions were prepared. The actual recipe based on $1 \mathrm{~L}$ is given in Table 3.2 in the order that the chemicals were added to the simulant. The $5 \mathrm{M}$ Na simulant was heated to $50^{\circ} \mathrm{C}$ and held for about 8 hours. This was enough for the simulant to clear of solids. The $7.8 \mathrm{M}$ Na simulant was heated to $75^{\circ} \mathrm{C}$ and held for about 80 minutes without most of the solids dissolving. After preparing both of the simulants, the selected COCs (iodine, lead, nickel, and cadmium as shown in Table 3.2) were added as solids to each simulant and mixed. The Ni, added as a nitrate, crystallized immediately when put into the simulants and did not re-dissolve. The other COCs dissolved completely upon addition to the simulants. The Ni-bearing solids were clearly distinguishable as they formed dark-colored precipitates. The wt\% solids values cited in Table 3.2 include both the dissolved solids and any undissolved solids that formed upon cooling or when the nickel nitrate was added. The wt\% solids were direct measurements of small aliquots of the simulant suspensions performed after adding the COCs to the large batches. The weights of the aliquots of suspension before drying and after drying were used to calculate the wt\% solids. 
Table 3.2. Recipe for SST Blend Saltcake Simulant Based on $1 \mathrm{~L}$

\begin{tabular}{|c|c|c|}
\hline Chemical & $\begin{array}{c}5 \text { M Na Simulant } \\
\text { Amount Needed (g) } \\
\text { Rounded to } 2 \\
\text { decimals }\end{array}$ & $\begin{array}{c}7.8 \text { M Na Simulant } \\
\text { Amount Needed (g) } \\
\text { Rounded to } 2 \\
\text { decimals }\end{array}$ \\
\hline $\mathrm{KNO}_{3}$ & 1.25 & 1.96 \\
\hline $\mathrm{NaCl}$ & 2.56 & 3.99 \\
\hline $\mathrm{NaF}$ & 1.33 & 2.07 \\
\hline $\mathrm{Na}_{2} \mathrm{SO}_{4}$ & 12.78 & 19.94 \\
\hline $\mathrm{Al}\left(\mathrm{NO}_{3}\right)_{3} \cdot 9 \mathrm{H}_{2} \mathrm{O}$ & 23.90 & 37.28 \\
\hline $\mathrm{NaNO}_{3}$ & 196.04 & 305.82 \\
\hline $\mathrm{NaOH}$ (50\% solution) & 59.18 & 92.32 \\
\hline $\mathrm{Na}_{3} \mathrm{PO}_{4} \cdot 12 \mathrm{H}_{2} \mathrm{O}$ & 18.70 & 29.18 \\
\hline $\mathrm{NaCH}_{3} \mathrm{COO}-3 \mathrm{H}_{2} \mathrm{O}$ & 17.89 & 27.92 \\
\hline $\mathrm{Na}_{2} \mathrm{CO}_{3} \cdot \mathrm{H}_{2} \mathrm{O}$ & 58.90 & 91.88 \\
\hline $\mathrm{NaNO}_{2}$ & 29.25 & 45.64 \\
\hline $\mathrm{Na}_{2} \mathrm{C}_{2} \mathrm{O}_{4}$ & 1.58 & 2.47 \\
\hline $\mathrm{Na}_{2} \mathrm{Cr}_{2} \mathrm{O}_{7} \cdot 2 \mathrm{H}_{2} \mathrm{O}$ & 1.55 & 2.42 \\
\hline \multicolumn{3}{|c|}{ COCs } \\
\hline $\mathrm{NaI}$ & 0.118 & 0.184 \\
\hline $\mathrm{Pb}\left(\mathrm{NO}_{3}\right)_{2}$ & 0.085 & 0.133 \\
\hline $\mathrm{Cd}\left(\mathrm{NO}_{3}\right)_{2} \cdot 4 \mathrm{H}_{2} \mathrm{O}$ & 0.049 & 0.077 \\
\hline $\mathrm{Ni}\left(\mathrm{NO}_{3}\right)_{2} \cdot 6 \mathrm{H}_{2} \mathrm{O}$ & 0.961 & 1.50 \\
\hline \multicolumn{3}{|c|}{\begin{tabular}{|c|} 
Physical Properties \\
\end{tabular}} \\
\hline Density before COCs added $\left(\mathrm{g} / \mathrm{cm}^{3}\right)$ & Not measured & Not measured \\
\hline Density after COCs added $\left(\mathrm{g} / \mathrm{cm}^{3}\right)$ & 1.23 & 1.36 \\
\hline Wt\% total solids before COCs added & 28.9 & 41.6 \\
\hline Wt\% total solids after COCs added & 28.2 & 41.2 \\
\hline
\end{tabular}

\subsection{Overall Average Simulant Results}

When the initial $5 \mathrm{M}$ Na simulant was prepared in a 1-L volumetric flask, significant solids formed leaving a $1 / 8$ " to $1 / 4 "$ layer of settled solids on the bottom of the flask. After the hydroxide was added, each chemical was not going into solution and solids remained. The simulant was then heated to $70^{\circ} \mathrm{C}$ for about 85 minutes and the simulant still contained solids. The simulant was then placed in a temperature controlled chamber at $25^{\circ} \mathrm{C}$ to cool. After cooling and being held at $25^{\circ} \mathrm{C}$ (see Figure 3.3), the amount of solids was measured and found to be about $18.055 \mathrm{~g}$ in the liter of solution or about $1.4 \mathrm{wt} \%$. It was decided that this composition had too many solids present to proceed and that the composition needed to be changed.

It was determined through inductively coupled plasma-optical emission spectroscopy (ICP-OES) and $\mathrm{X}$-ray diffraction (XRD) that the solids present were primarily sodium fluorophosphate salt $\left(\mathrm{Na}_{7} \mathrm{~F}\left(\mathrm{PO}_{4}\right)_{3} \cdot 19 \mathrm{H}_{2} 0\right)$. It was documented in Rassat et al. (2003) that the phosphate level in the SST blend saltcake simulant had to be reduced to preclude sodium fluorophosphate salts from forming. The SST 
blend saltcake simulant composition formulated by Rassat et al. remained in solution. Therefore, it was decided to reduce the phosphate and fluoride levels in the overall average simulant to those concentrations used in the SST blend saltcake simulant. This entailed reducing the phosphate by about $30 \%$ relative to the HTWOS composition and the fluoride by about $75 \%$. This was deemed reasonable since fluoride is not expected to have notable effects on the Cast Stone formulation (i.e., participate in the hydration reactions) and would not be present in real waste at $5 \mathrm{M}$ Na concentration because any fluorophosphate precipitate present would be filtered out during pretreatment.

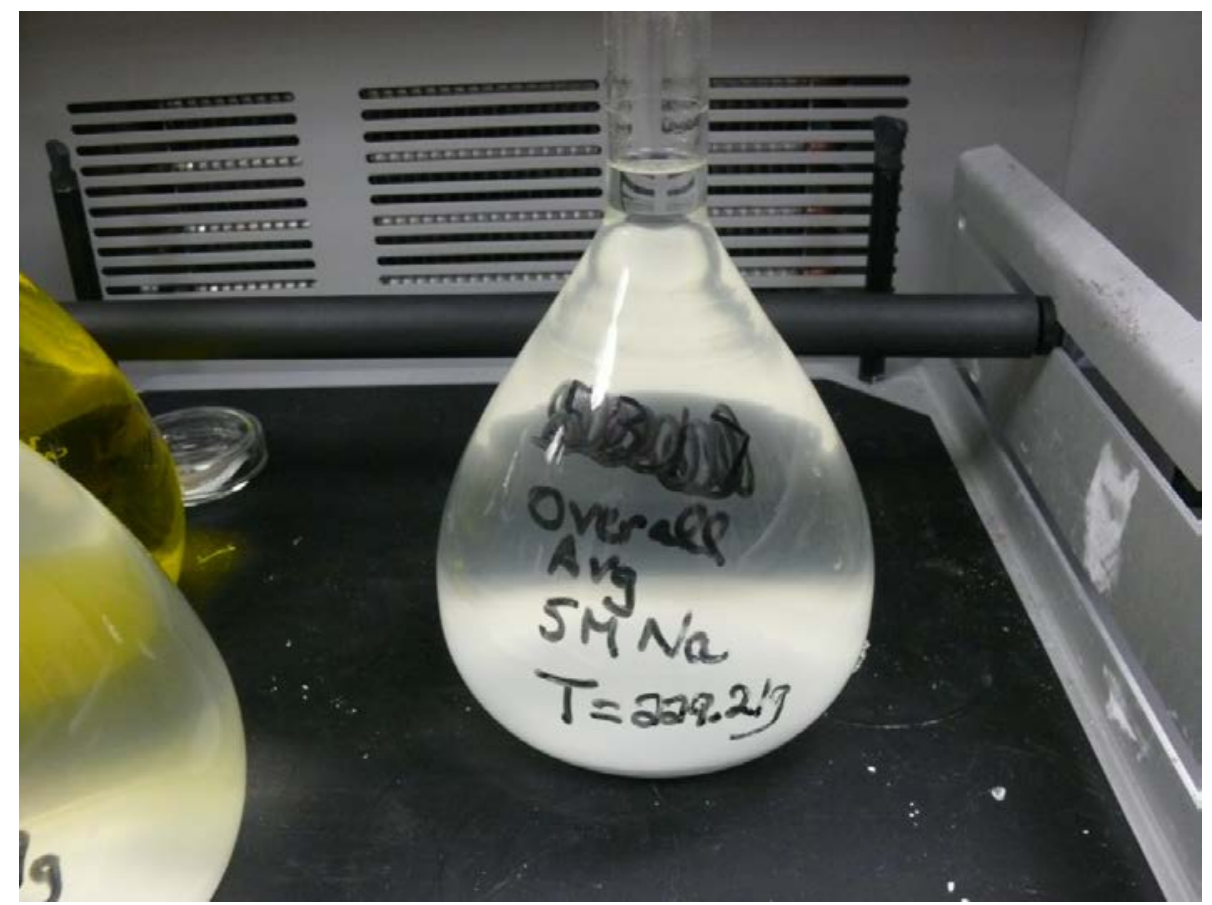

Figure 3.3. $5 \mathrm{M} \mathrm{Na}$ Overall Average Simulant after Cooling at $25^{\circ} \mathrm{C}$

Another $5 \mathrm{M} \mathrm{Na}$ overall average simulant was prepared using this revised composition. After the addition of all the chemicals there were solids still present. The simulant was then heated to $55^{\circ} \mathrm{C}$ for about 15 minutes and the simulant completely cleared at about $50^{\circ} \mathrm{C}$ as shown in Figure 3.4. It was then placed in a controlled temperature chamber at $25^{\circ} \mathrm{C}$ to cool. No solids formed over time. It was then decided that this composition was adequate to proceed with Cast Stone fabrication and testing.

A 7.8 $\mathrm{M}$ Na overall average simulant was made using the revised composition $5 \mathrm{M}$ Na recipe scaled to $7.8 \mathrm{M}$ Na concentration in a $1 \mathrm{~L}$ volumetric flask. With this simulant, solids were present after mixing and each chemical was not going into solution after the hydroxide was added. The simulant was heated to $90^{\circ} \mathrm{C}$ and held for about 2 hours and the simulant cleared. It was then placed in a controlled temperature chamber at $25^{\circ} \mathrm{C}$ to cool. After cooling and being held at $25^{\circ} \mathrm{C}$, a few crystals had formed on the bottom of the flask.

Based on these results, it was decided to proceed with the large batch simulant needed for the Cast Stone preparation. Twelve-liter batches of both the $5 \mathrm{M}$ Na and 7.8 $\mathrm{M}$ Na compositions were prepared. The actual recipe based on $1 \mathrm{~L}$ is given in Table 3.3 in the order that the chemicals were added to the simulant. The $5 \mathrm{M}$ Na simulant was heated to $55^{\circ} \mathrm{C}$ and held for about 2 hours. This was sufficient time 
for the simulant to clear of solids. The $7.8 \mathrm{M}$ Na simulant was heated to $65^{\circ} \mathrm{C}$ and held for about 2 hours with most of the solids dissolving. After cooling, more solids precipitated out of the $7.8 \mathrm{M}$ solution. After preparing both of the simulants, the COCs of interest were added as dry solids to each simulant and mixed. The Ni, added as a nitrate, precipitated immediately when put into the simulants and did not re-dissolve. The other COCs dissolved completely upon addition to the simulants. The Ni-bearing solids were clearly distinguishable as they formed dark-colored precipitate. The wt $\%$ solids values cited in Table 3.3 include both the dissolved solids and any undissolved solids that formed upon cooling or when the nickel nitrate was added. The wt\% solids were direct measurements of small aliquots of the simulant suspensions performed both before and after adding the COCs to the large batches. The weights of the aliquots of suspension before drying and after drying were used to calculate the wt\% solids.

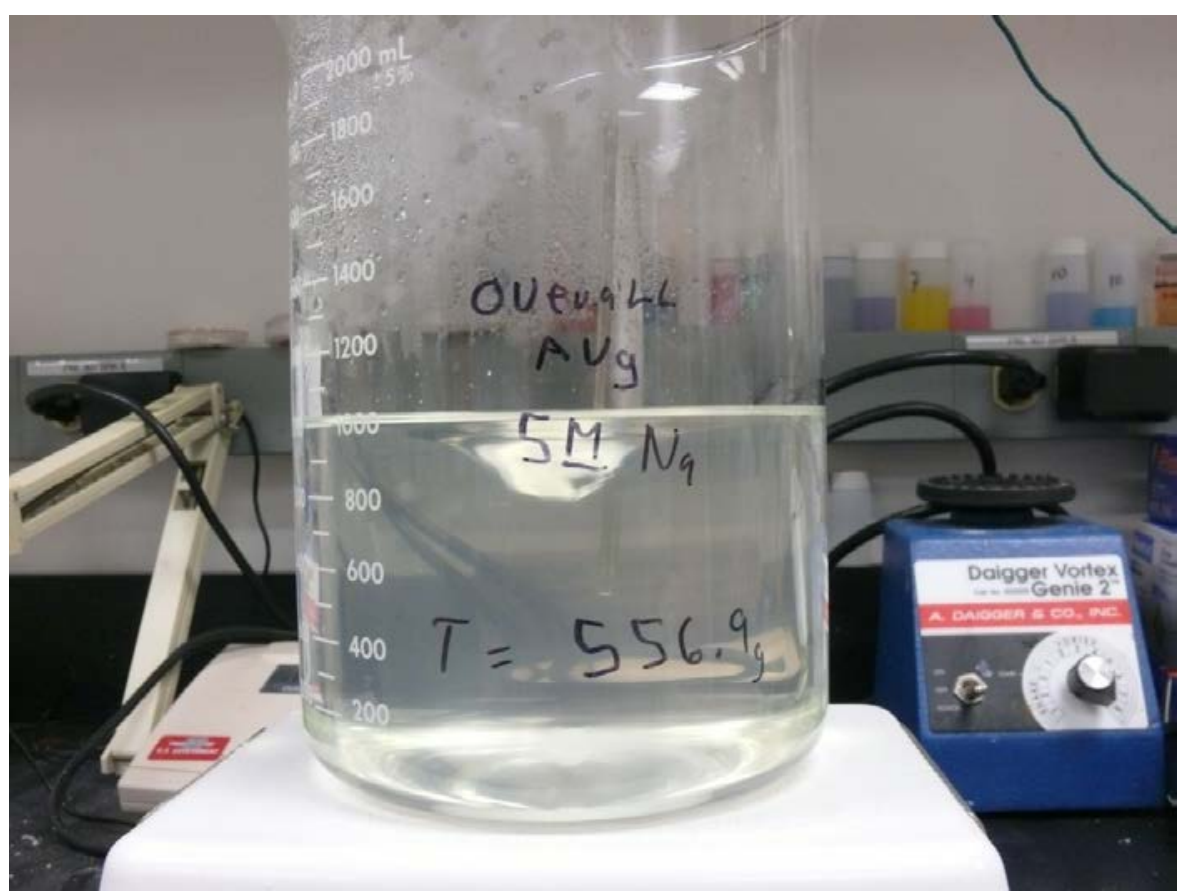

Figure 3.4. $5 \mathrm{M}$ Na New Composition Overall Average Simulant after Heating 
Table 3.3. Recipe for Overall Average Simulant Based on $1 \mathrm{~L}$

\begin{tabular}{|c|c|c|}
\hline Chemical & $\begin{array}{c}5 \text { M Na Simulant } \\
\text { Amount Needed (g) } \\
\text { Rounded to } 2 \\
\text { decimals }\end{array}$ & $\begin{array}{c}7.8 \text { M Na Simulant } \\
\text { Amount Needed (g) } \\
\text { Rounded to } 2 \\
\text { decimals }\end{array}$ \\
\hline $\mathrm{KNO}_{3}$ & 3.31 & 5.17 \\
\hline $\mathrm{NaCl}$ & 2.47 & 3.85 \\
\hline $\mathrm{NaF}$ & 1.33 & 2.07 \\
\hline $\mathrm{Na}_{2} \mathrm{SO}_{4}$ & 12.15 & 18.95 \\
\hline $\mathrm{Al}\left(\mathrm{NO}_{3}\right)_{3} \cdot 9 \mathrm{H}_{2} \mathrm{O}$ & 115.09 & 179.54 \\
\hline $\mathrm{NaNO}_{3}$ & 56.86 & 88.70 \\
\hline $\mathrm{NaOH}$ (50\% solution) & 222.96 & 347.81 \\
\hline $\mathrm{Na}_{3} \mathrm{PO}_{4} \cdot 12 \mathrm{H}_{2} \mathrm{O}$ & 18.70 & 29.18 \\
\hline $\mathrm{NaCH}_{3} \mathrm{COO} \cdot 3 \mathrm{H}_{2} \mathrm{O}$ & 5.22 & 8.14 \\
\hline $\mathrm{Na}_{2} \mathrm{CO}_{3} \cdot \mathrm{H}_{2} \mathrm{O}$ & 33.99 & 53.03 \\
\hline $\mathrm{NaNO}_{2}$ & 38.97 & 60.80 \\
\hline \multicolumn{3}{|c|}{ COCs } \\
\hline $\mathrm{NaI}$ & 0.118 & 0.184 \\
\hline $\mathrm{Pb}\left(\mathrm{NO}_{3}\right)_{2}$ & 0.085 & 0.133 \\
\hline $\mathrm{Na}_{2} \mathrm{Cr}_{2} \mathrm{O}_{7} \cdot 2 \mathrm{H}_{2} \mathrm{O}$ & 3.20 & 5.00 \\
\hline $\mathrm{Cd}\left(\mathrm{NO}_{3}\right)_{2} \cdot 4 \mathrm{H}_{2} \mathrm{O}$ & 0.049 & 0.077 \\
\hline $\mathrm{Ni}\left(\mathrm{NO}_{3}\right)_{2} \cdot 6 \mathrm{H}_{2} \mathrm{O}$ & 0.961 & 1.50 \\
\hline \multicolumn{3}{|c|}{\begin{tabular}{|l} 
Physical Properties \\
\end{tabular}} \\
\hline Density before COCs added $\left(\mathrm{g} / \mathrm{cm}^{3}\right)$ & 1.23 & 1.34 \\
\hline Density after RCRA added $\left(\mathrm{g} / \mathrm{cm}^{3}\right)$ & 1.23 & 1.34 \\
\hline $\begin{array}{l}\text { Wt\% total solids before COCs } \\
\text { added }\end{array}$ & 26.5 & 38.6 \\
\hline $\mathrm{Wt} \%$ total solids after COCs added & 26.9 & 38.6 \\
\hline
\end{tabular}

\subsection{High $\mathrm{Al}^{+3}$ and $\mathrm{Cl}^{-}$Simulant Results}

When the initial $5 \mathrm{M}$ Na High $\mathrm{Al}$ and $\mathrm{Cl}$ simulant was prepared in a 1-L volumetric flask, not many solids formed. The simulant was slightly cloudy and a very thin coating of solids was present on the bottom of the flask as shown in Figure 3.5. Each chemical added went into solution well. The simulant was then heated to $71^{\circ} \mathrm{C}$ for about 80 minutes and the simulant cleared completely as shown in Figure 3.6. It was then placed in a temperature controlled chamber at $25^{\circ} \mathrm{C}$ to cool. After cooling and being held at $25^{\circ} \mathrm{C}$, the amount of solids was measured and found to be about $0.06 \mathrm{~g}$ in the liter of solution (or about $0.005 \mathrm{wt} \%$ which is less than the $<0.1 \mathrm{wt} \%$ criteria). It was decided that this composition was adequate to proceed with testing. 


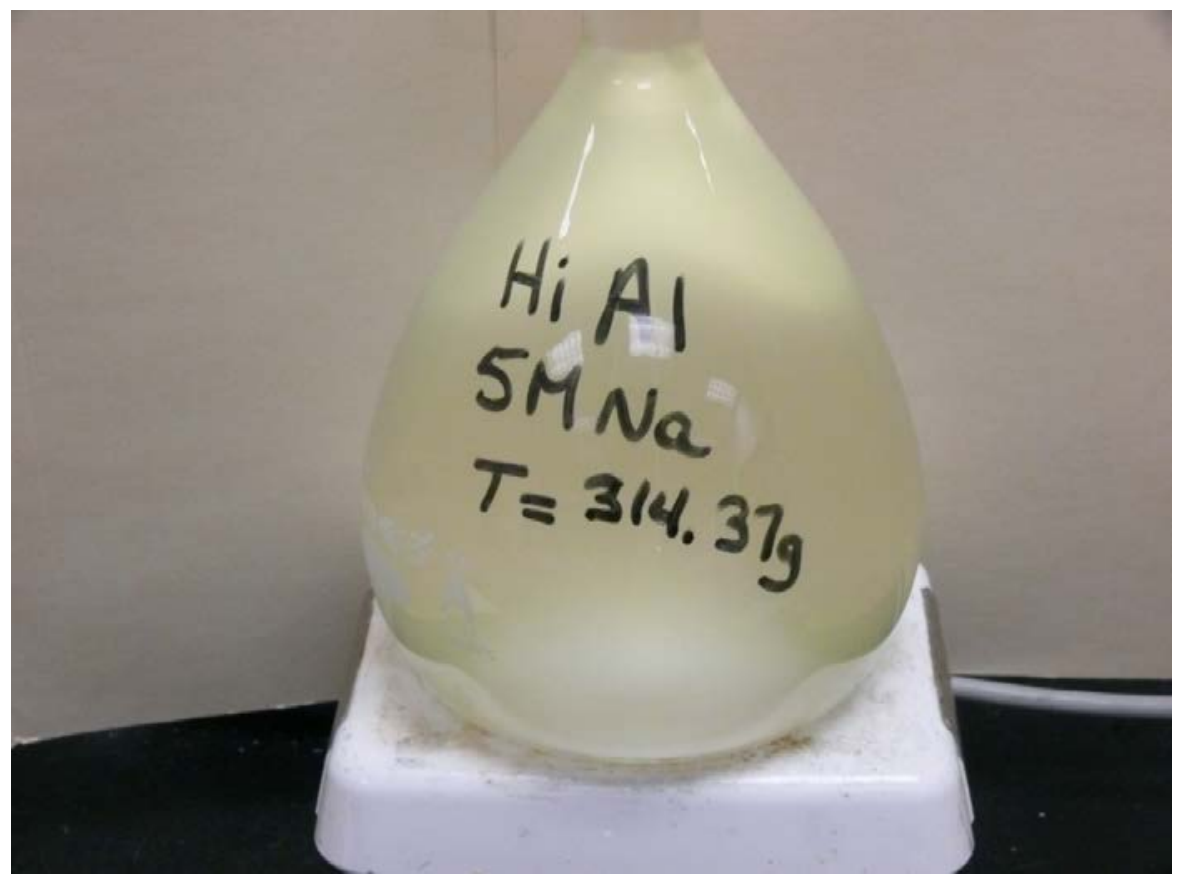

Figure 3.5. $5 \mathrm{M}$ Na High-Al Simulant before Heating

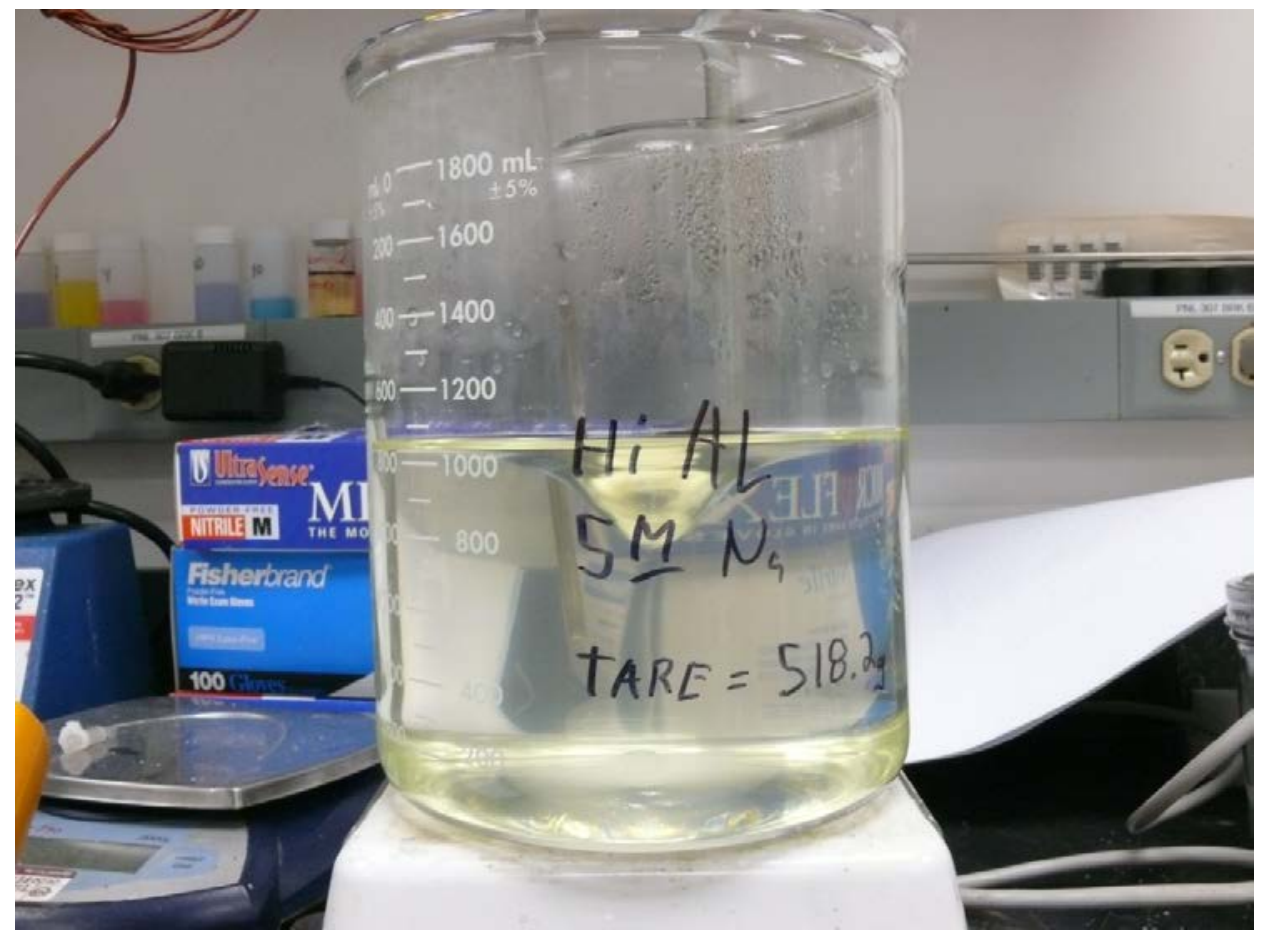

Figure 3.6. $5 \mathrm{M}$ Na High-Al Simulant after Heating and before Cooling

A 7.8 $\mathrm{M}$ Na simulant was made using the same recipe adjusted for the change in Na concentration in a 1-L volumetric flask. With this simulant there were solids present after mixing and each chemical was not going into solution well after the hydroxide was added as shown in Figure 3.7. The simulant was 
heated to $84^{\circ} \mathrm{C}$ and held for about 140 minutes and the simulant cleared. It was then placed in a temperature controlled chamber at $25^{\circ} \mathrm{C}$ to cool. After cooling and being held at $25^{\circ} \mathrm{C}$, a few crystals had formed on the bottom of the flask as shown in Figure 3.8.

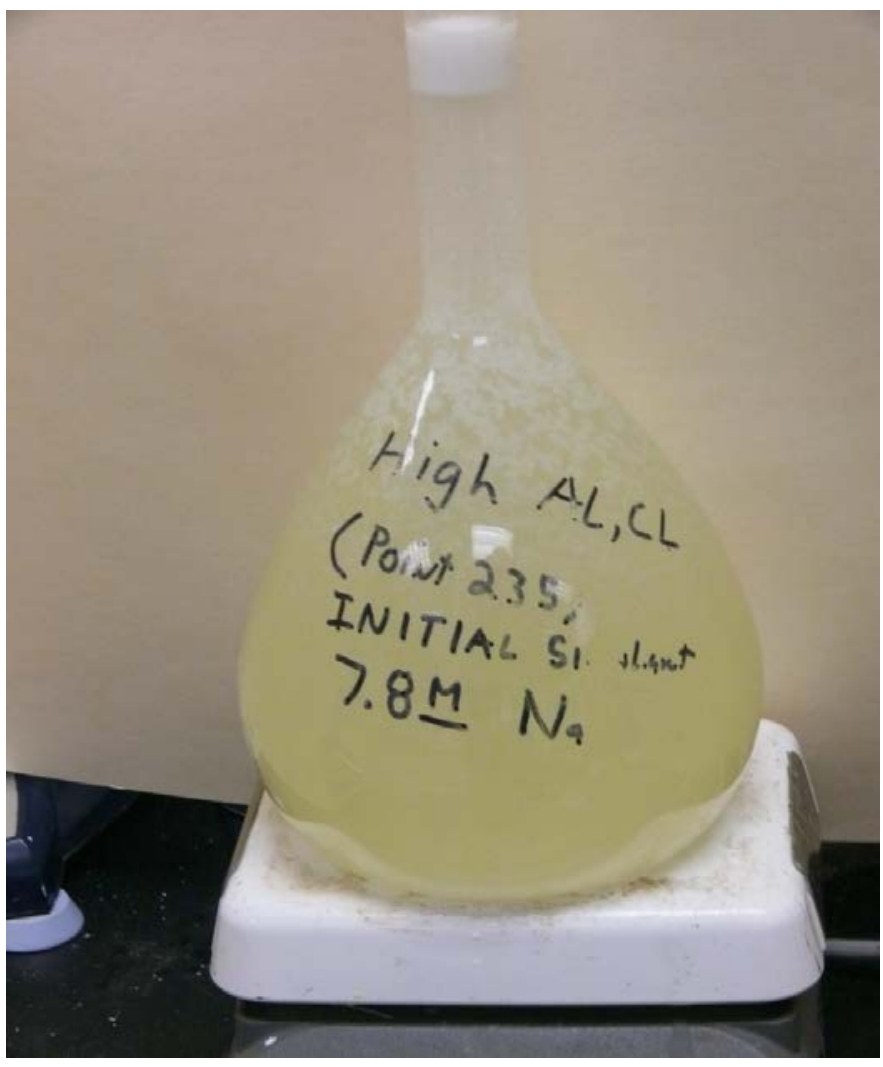

Figure 3.7. 7.8 M Na High-Al Simulant before Heating 


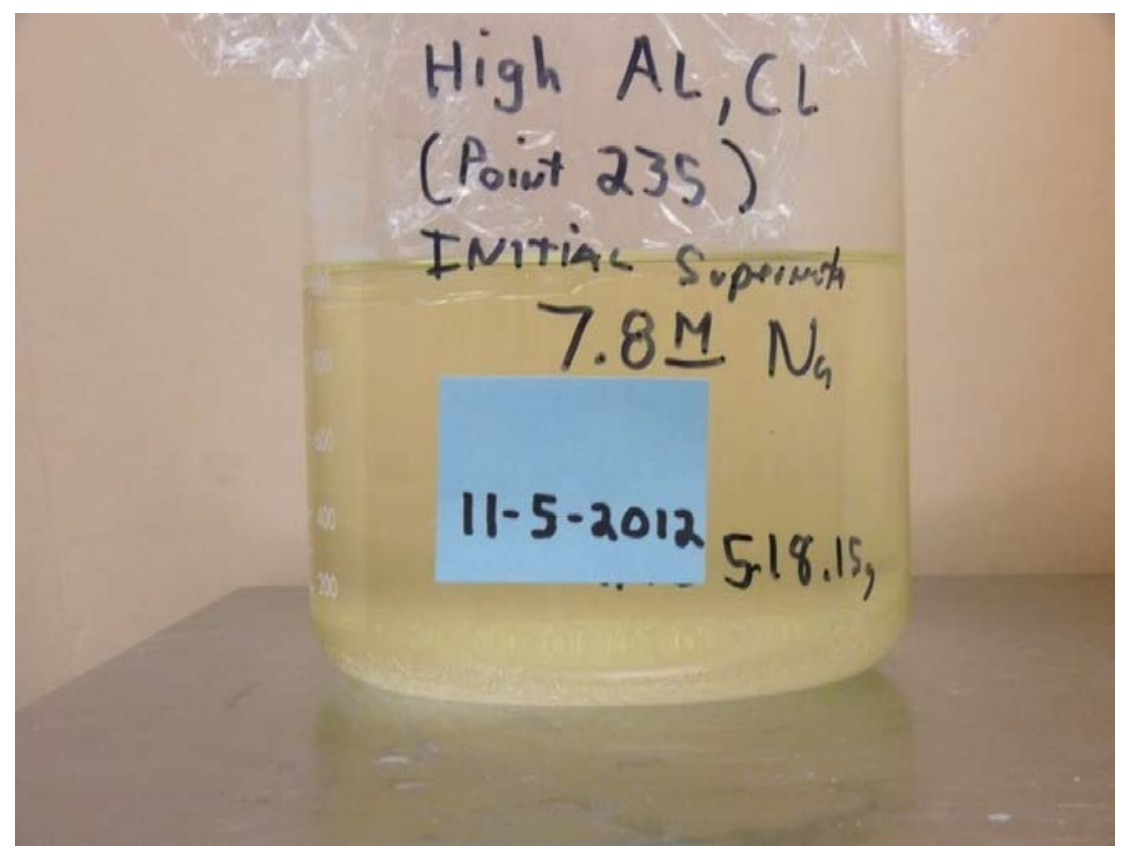

Figure 3.8. $7.8 \mathrm{M}$ Na High-Al Simulant after Heating and Cooling

Based on these results, it was decided to proceed with the large batch simulant needed for the Cast Stone preparation. Eleven-liter batches of both the $5 \mathrm{M} \mathrm{Na}$ and $7.8 \mathrm{M} \mathrm{Na} \mathrm{High} \mathrm{Al}$ and $\mathrm{Cl}$ compositions were prepared. The actual recipe based on $1 \mathrm{~L}$ is given in Table 3.4 in the order the chemicals were added to the simulant. The $5 \mathrm{M} \mathrm{Na}$ simulant was heated to $40^{\circ} \mathrm{C}$ and held for about 30 minutes. This was enough for the simulant to clear of solids. The $7.8 \mathrm{M}$ Na simulant was heated to $70^{\circ} \mathrm{C}$ and held for about 2 hours with most of the solids dissolving. After preparing both of the simulants, the selected COCs were added as dry solids to each simulant and mixed. The Ni, added as a nitrate, precipitated immediately when put into the simulants and did not re-dissolve. The other COCs dissolved completely upon addition to the simulants. The Ni-bearing solids were clearly distinguishable as they formed dark-colored precipitate. The wt\% solids values cited in Table 3.4 include both the dissolved solids and any undissolved solids that formed upon cooling or when the nickel nitrate was added. The wt\% solids were direct measurements of small aliquots of the simulant suspensions performed after adding the COCs to the large batches. The weights of the aliquots of suspension before drying and after drying were used to calculate the wt $\%$ solids. 
Table 3.4. Recipe for High-Al and -Cl Simulant Based on $1 \mathrm{~L}$

\begin{tabular}{|c|c|c|}
\hline Chemical & $\begin{array}{c}5 \text { M Na Simulant } \\
\text { Amount Needed (g) } \\
\text { Rounded to } 2 \\
\text { decimals } \\
\end{array}$ & $\begin{array}{c}7.8 \text { M Na Simulant } \\
\text { Amount Needed (g) } \\
\text { Rounded to } 2 \\
\text { decimals } \\
\end{array}$ \\
\hline $\mathrm{KOH}$ & 7.91 & 12.34 \\
\hline $\mathrm{NaCl}$ & 5.32 & 8.30 \\
\hline $\mathrm{NaF}$ & 2.12 & 3.31 \\
\hline $\mathrm{Al}_{2}\left(\mathrm{SO}_{4}\right)_{3} \cdot 18 \mathrm{H}_{2} \mathrm{O}$ & 4.87 & 7.60 \\
\hline $\mathrm{Al}\left(\mathrm{NO}_{3}\right)_{3} \cdot 9 \mathrm{H}_{2} \mathrm{O}$ & 179.34 & 279.78 \\
\hline $\mathrm{NaAlO}_{2}$ & 5.52 & 8.62 \\
\hline $\mathrm{NaOH}$ (50\% solution) & 263.62 & 411.25 \\
\hline $\mathrm{Na}_{3} \mathrm{PO}_{4} \cdot 12 \mathrm{H}_{2} \mathrm{O}$ & 10.03 & 15.64 \\
\hline $\mathrm{NaCH}_{3} \mathrm{COO} \cdot 3 \mathrm{H}_{2} \mathrm{O}$ & 7.12 & 11.11 \\
\hline $\mathrm{Na}_{2} \mathrm{CO}_{3} \cdot \mathrm{H}_{2} \mathrm{O}$ & 24.54 & 38.27 \\
\hline $\mathrm{NaNO}_{2}$ & 66.81 & 104.23 \\
\hline \multicolumn{3}{|c|}{ COCs } \\
\hline $\mathrm{NaI}$ & 0.118 & 0.184 \\
\hline $\mathrm{Pb}\left(\mathrm{NO}_{3}\right)_{2}$ & 0.085 & 0.133 \\
\hline $\mathrm{Na}_{2} \mathrm{Cr}_{2} \mathrm{O}_{7} \cdot 2 \mathrm{H}_{2} \mathrm{O}$ & 3.20 & 5.00 \\
\hline $\mathrm{Cd}\left(\mathrm{NO}_{3}\right)_{2} \cdot 4 \mathrm{H}_{2} \mathrm{O}$ & 0.049 & 0.077 \\
\hline $\mathrm{Ni}\left(\mathrm{NO}_{3}\right)_{2} \cdot 6 \mathrm{H}_{2} \mathrm{O}$ & 0.961 & 1.50 \\
\hline \multicolumn{3}{|c|}{ Physical Properties } \\
\hline Density before COCs added & 1.23 & 1.36 \\
\hline Density after COCs added & 1.22 & 1.37 \\
\hline $\mathrm{Wt} \%$ total solids before COCs added & 27.5 & 40.5 \\
\hline $\mathrm{Wt} \%$ total solids after COCs added & 27.8 & 40.9 \\
\hline
\end{tabular}

\subsection{High $\mathrm{SO}_{4}^{-2}$ Simulant Results}

When the initial $5 \mathrm{M}$ Na high-sulfate simulant was prepared in a 1-L volumetric flask, significant solids formed on the bottom of the flask. Each chemical was not going into solution well after the hydroxide was added, as shown in Figure 3.9. The simulant was then heated to $91^{\circ} \mathrm{C}$ for about 2 hours and the simulant still contained significant solids, as shown in Figure 3.10. It was then placed in a temperature controlled chamber at $25^{\circ} \mathrm{C}$ to cool. After cooling and being held at $25^{\circ} \mathrm{C}$, the amount of solids was measured and found to be about $144.3 \mathrm{~g}$ in the liter of solution (about $12 \mathrm{wt} \%$ ). It was decided that this composition had too many solids present to proceed and that the composition needed to be changed. 


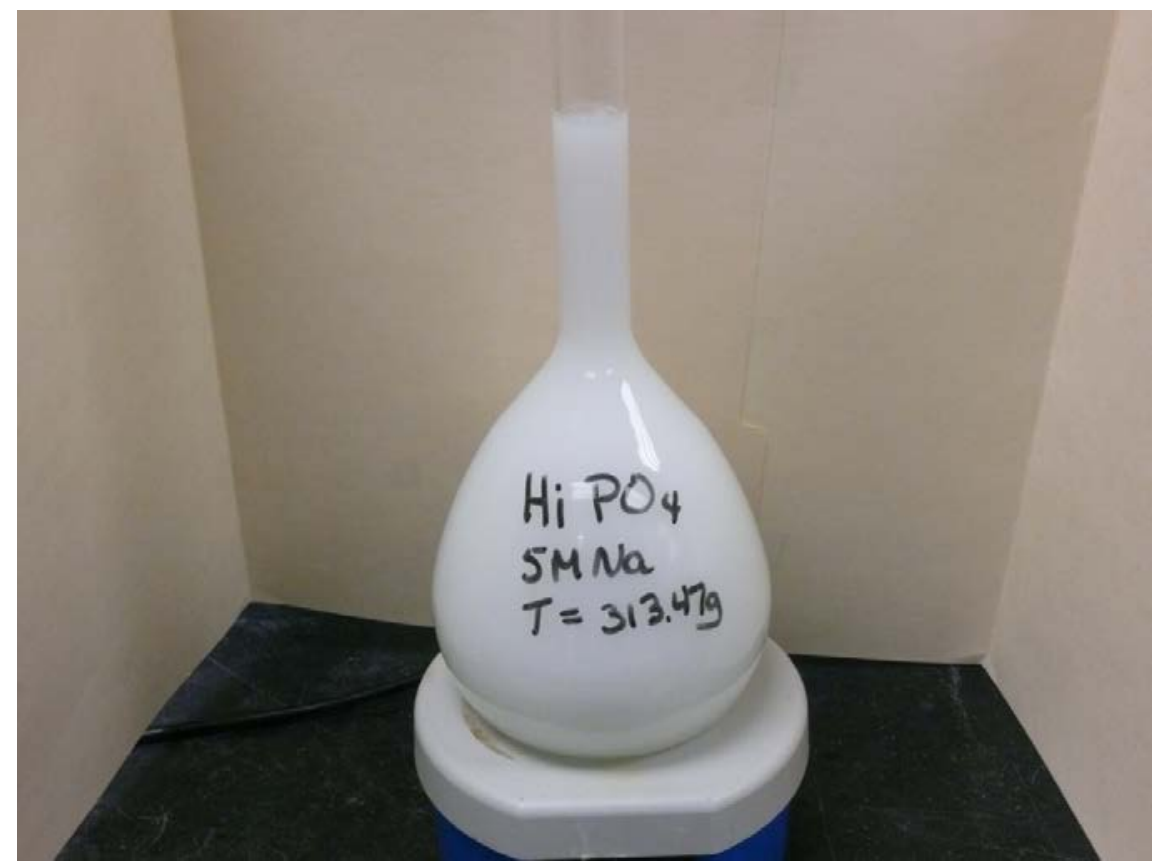

Figure 3.9. $5 \mathrm{M} \mathrm{Na}$ High- $\mathrm{SO}_{4}{ }^{-2}$ Simulant while Mixing

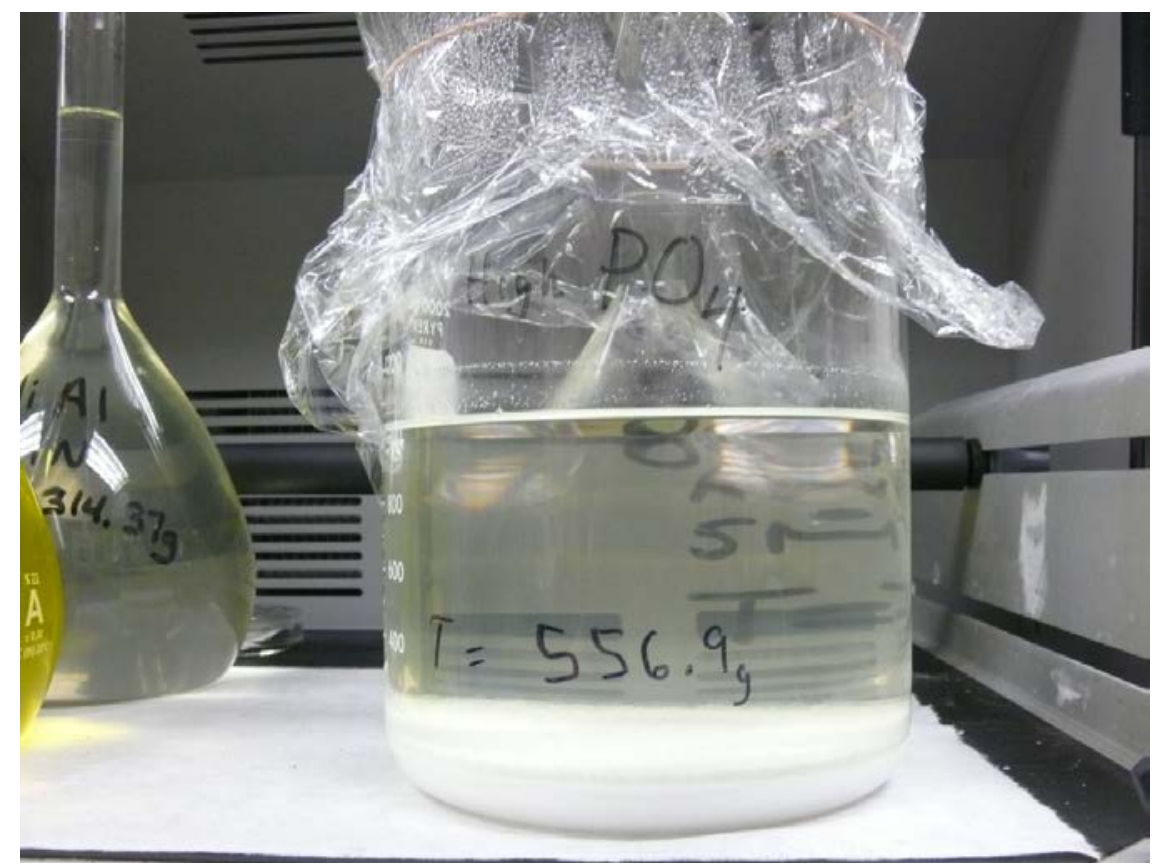

Figure 3.10. $5 \mathrm{M}$ Na High-SO ${ }_{4}^{-2}$ Simulant after Heating

It was determined through ICP-OES and XRD that the solids present contained a substantial amount of sodium fluorophosphate salt. It was mentioned in Rassat et al. (2003) that the phosphate level in that simulant had to be reduced to eliminate the sodium fluorophosphate salts from forming. The composition of the SST blend saltcake simulant remained in solution and therefore, it was decided to reduce the phosphate and fluoride levels in the high sulfate simulant to those contained in the SST blend saltcake simulant. 
Another $5 \mathrm{M}$ Na high sulfate simulant was prepared using this revised composition. After the addition of all chemicals there were a few solids present. The simulant was then heated to $41^{\circ} \mathrm{C}$ for about 30 minutes and the simulant completely cleared at about $39.5^{\circ} \mathrm{C}$. It was then placed in a temperature controlled chamber at $25^{\circ} \mathrm{C}$ to cool. No solids formed over time.

An experiment was conducted attempting to increase the fluoride concentration to $0.1 \mathrm{M}$. Sodium fluoride was added to the simulant in increments of $0.02 \mathrm{M}$ and allowed to dissolve. After reaching $0.08 \mathrm{M} \mathrm{F}^{-}$, precipitate formed and it would no longer go into solution. It was decided based on these results to increase the fluoride concentration to $0.06 \mathrm{M}$ in the $5 \mathrm{M}$ Na high sulfate simulant since that amount went into solution without precipitating. Based on these results, this composition was used to proceed with testing. A 7.8 M Na high sulfate simulant was not prepared as it was decided that whatever solids formed would just be managed in the same manner as with the other simulants - heated to drive as much of the solids into solution as practical then cooled slowly to $25^{\circ} \mathrm{C}$.

Based on these results, it was decided to proceed with the large batch high sulfate simulant needed for the Cast Stone preparation. Thirteen-liter batches of both the $5 \mathrm{M}$ Na and 7.8 M Na compositions were prepared. The actual recipe for each total Na concentration in the high sulfate simulant based on $1 \mathrm{~L}$ is given in Table 3.5 in the order that the chemicals were added to the simulant. The $5 \mathrm{M}$ Na simulant was heated to $60^{\circ} \mathrm{C}$ and held for about 2 hours. This was enough for the simulant to clear of solids. The 7.8 $\mathrm{M} \mathrm{Na}$ simulant was heated to $60^{\circ} \mathrm{C}$ and held for about 1 hour with only part of the solids dissolving. After cooling, more solids precipitated out of the high sulfate $7.8 \mathrm{M}$ solution. After preparing both of the simulants, the selected COCs were added as dry solids to each simulant and mixed. The Ni, added as a nitrate, precipitated immediately when put into the simulants and did not re-dissolve. The other COCs dissolved completely upon addition to the simulants. The Ni-bearing solids were clearly distinguishable as they formed dark-colored precipitate. The wt\% solids values cited in Table 3.3 include both the dissolved solids and any undissolved solids that formed upon cooling or when the nickel nitrate was added. The wt $\%$ solids were direct measurements of small aliquots of the simulant suspensions performed after adding the COCs to the large batches. The weights of the aliquots of suspension before drying and after drying were used to calculate the wt $\%$ solids. 
Table 3.5. Recipe for High Sulfate Simulant Based on $1 \mathrm{~L}$

\begin{tabular}{|c|c|c|}
\hline Chemical & $\begin{array}{c}5 \text { M Na Simulant } \\
\text { Amount Needed (g) } \\
\text { Rounded to } 2 \\
\text { decimals }\end{array}$ & $\begin{array}{c}7.8 \text { M Na Simulant } \\
\text { Amount Needed (g) } \\
\text { Rounded to } 2 \\
\text { decimals }\end{array}$ \\
\hline $\mathrm{NaCl}$ & 2.02 & 3.15 \\
\hline $\mathrm{NaF}$ & 2.52 & 3.93 \\
\hline $\mathrm{Na}_{2} \mathrm{SO}_{4}$ & 21.31 & 33.24 \\
\hline $\mathrm{Al}\left(\mathrm{NO}_{3}\right)_{3} \cdot 9 \mathrm{H}_{2} \mathrm{O}$ & 87.64 & 136.73 \\
\hline $\mathrm{NaNO}_{3}$ & 96.36 & 150.32 \\
\hline $\mathrm{NaOH}$ ( $50 \%$ solution) & 98.64 & 153.87 \\
\hline $\mathrm{Na}_{3} \mathrm{PO}_{4} \cdot 12 \mathrm{H}_{2} \mathrm{O}$ & 18.70 & 29.18 \\
\hline $\mathrm{NaCH}_{3} \mathrm{COO} \cdot 3 \mathrm{H}_{2} \mathrm{O}$ & 2.55 & 3.97 \\
\hline $\mathrm{Na}_{2} \mathrm{CO}_{3} \cdot \mathrm{H}_{2} \mathrm{O}$ & 21.58 & 33.67 \\
\hline $\mathrm{NaNO}_{2}$ & 33.90 & 52.88 \\
\hline \multicolumn{3}{|c|}{ COCs } \\
\hline $\mathrm{NaI}$ & 0.118 & 0.184 \\
\hline $\mathrm{Pb}\left(\mathrm{NO}_{3}\right)_{2}$ & 0.085 & 0.133 \\
\hline $\mathrm{Na}_{2} \mathrm{Cr}_{2} \mathrm{O}_{7} \cdot 2 \mathrm{H}_{2} \mathrm{O}$ & 3.20 & 5.00 \\
\hline $\mathrm{Cd}\left(\mathrm{NO}_{3}\right)_{2} \cdot 4 \mathrm{H}_{2} \mathrm{O}$ & 0.049 & 0.077 \\
\hline $\mathrm{Ni}\left(\mathrm{NO}_{3}\right)_{2} \cdot 6 \mathrm{H}_{2} \mathrm{O}$ & 0.961 & 1.50 \\
\hline \multicolumn{3}{|c|}{ Physical Properties } \\
\hline $\begin{array}{l}\text { Density before COCs added } \\
\left(\mathrm{g} / \mathrm{cm}^{3}\right)\end{array}$ & 1.23 & 1.32 \\
\hline Density after COCs added $\left(\mathrm{g} / \mathrm{cm}^{3}\right)$ & 1.23 & 1.34 \\
\hline Wt\% solids before RCRA added & 26.5 & 36.9 \\
\hline Wt\% solids after RCRA added & 26.8 & 37.8 \\
\hline
\end{tabular}

\subsection{Final Simulant Analytical Results}

The final compositions of the simulants used for the Cast Stone preparation at Pacific Northwest National Laboratory (PNNL) were analyzed and compared to Savannah River National Laboratory's (SRNL's) simulant analysis. These are shown in Table 3.6 through Table 3.9. The analyses are based on samples of the large batches prepared for each simulant. Because the technetium and uranium spikes were not added until the individual Cast Stone batches were prepared at PNNL, analytical results for those species are not available. They will be determined based on analyses of the individual Cast Stone samples. Technetium and uranium were not used in the simulants at SRNL.

To sample the large batches of simulants, a mechanical agitator was used to stir the simulants. A peristaltic pump was used to withdraw aliquots from the middle of the vessel as it was being stirred. The constituent concentrations were determined using ICP-OES, ICP-MS, and ion chromatography. Free hydroxide was measured by titration to a $\mathrm{pH}$ of 9.8 using sulfuric acid. 
The analyzed compositions were reviewed for differences from the target compositions and differences between the PNNL and SRNL simulant compositions. In general, differences of approximately $+/-10 \%$ from the target for the major constituents were considered acceptable. For the minor constituents and RCRA spikes, differences greater than $+/-10 \%$ from the target were evaluated to determine if the cause of the variation could be identified and whether it was considered likely to impact the testing results. Differences between supernate and total analyzed compositions were reviewed as indicators of the type of solids that may have formed in the simulants. Based on these reviews, none of the variations were considered likely to impact testing results and the simulants were considered to be in reasonable agreement with the target compositions and between the two labs. 
Table 3.6. Analytical Results for 5 M Na SST Blend Saltcake Simulant Compositions

\begin{tabular}{|c|c|c|c|c|c|}
\hline \multirow[b]{2}{*}{ Component } & \multirow[b]{2}{*}{$\begin{array}{l}\text { Target Total } \\
\text { (g/L) }\end{array}$} & \multicolumn{2}{|c|}{ PNNL } & \multicolumn{2}{|c|}{ SRNL } \\
\hline & & $\begin{array}{l}\text { Supernate } \\
(\mathrm{g} / \mathrm{L})\end{array}$ & $\begin{array}{l}\text { Total } \\
(\mathrm{g} / \mathrm{L})\end{array}$ & $\begin{array}{c}\text { Supernate } \\
(\mathrm{g} / \mathrm{L})\end{array}$ & $\begin{array}{l}\text { Total } \\
\text { (g/L) }\end{array}$ \\
\hline \multicolumn{6}{|c|}{ Major Components } \\
\hline $\mathrm{Na}$ & 115 & 112 & 117 & 110 & 114 \\
\hline $\mathrm{Al}$ & 1.72 & 1.50 & 1.76 & 1.68 & 1.69 \\
\hline K & 0.485 & 0.431 & 0.39 & 0.614 & 0.625 \\
\hline $\mathrm{P}$ & 1.52 & 1.44 & 1.56 & 1.52 & 1.49 \\
\hline S & 2.89 & 2.95 & 3.27 & 2.84 & 2.83 \\
\hline $\mathrm{NO}_{3}^{-}$ & 156 & 164 & Not analyzed & 153 & Not analyzed \\
\hline $\mathrm{NO}_{2}^{-}$ & 19.5 & 20.2 & Not analyzed & 15.4 & Not analyzed \\
\hline $\mathrm{Cl}$ & 1.55 & 1.57 & Not analyzed & 1.48 & Not analyzed \\
\hline $\mathrm{F}$ & 0.600 & 0.558 & Not analyzed & 0.577 & Not analyzed \\
\hline $\mathrm{CO}_{3}^{-2}$ & 28.5 & Not analyzed & Not analyzed & Not analyzed & Not analyzed \\
\hline TOC & 3.16 & 3.74 & Not analyzed & Not analyzed & Not analyzed \\
\hline $\mathrm{OH}^{-}$ & 8.25 & 14.7 & Not analyzed & Not analyzed & Not analyzed \\
\hline \multicolumn{6}{|c|}{ Spike Components } \\
\hline $\mathrm{Cr}$ & 0.541 & 0.502 & 0.567 & 0.474 & 0.471 \\
\hline $\mathrm{Ni}$ & 0.194 & $<0.023$ & 0.079 & $<0.001$ & 0.162 \\
\hline $\mathrm{Pb}$ & 0.053 & 0.0456 & 0.060 & 0.0424 & 0.046 \\
\hline $\mathrm{Cd}$ & 0.0179 & 0.00021 & 0.0096 & $<0.001$ & 0.013 \\
\hline I & 0.100 & 0.0914 & Not analyzed & 0.088 & Not analyzed \\
\hline${ }^{99} \mathrm{Tc}$ & 0.0122 & Not analyzed & Not analyzed & Not added & Not added \\
\hline $\mathrm{U}$ & 0.178 & Not analyzed & Not analyzed & Not added & Not added \\
\hline
\end{tabular}


Table 3.7. Analytical Results for 7.8 M Na SST Blend Saltcake Simulant Compositions

\begin{tabular}{|c|c|c|c|c|c|}
\hline \multirow[b]{2}{*}{ Component } & \multirow[b]{2}{*}{$\begin{array}{c}\text { Target } \\
(\mathrm{g} / \mathrm{L})\end{array}$} & \multicolumn{2}{|c|}{ PNNL } & \multicolumn{2}{|c|}{ SRNL } \\
\hline & & $\begin{array}{l}\text { Supernate } \\
(\mathrm{g} / \mathrm{L})\end{array}$ & $\begin{array}{l}\text { Total } \\
\text { (g/L) }\end{array}$ & $\begin{array}{c}\text { Supernate } \\
(\mathrm{g} / \mathrm{L})\end{array}$ & $\begin{array}{c}\text { Total } \\
\text { (g/L) }\end{array}$ \\
\hline \multicolumn{6}{|c|}{ Major Components } \\
\hline $\mathrm{Na}$ & 179 & 172 & 195 & 164 & 177 \\
\hline $\mathrm{Al}$ & 2.68 & 2.46 & 2.97 & 2.64 & 2.68 \\
\hline K & 0.756 & 0.743 & 0.692 & 0.971 & 0.967 \\
\hline $\mathrm{P}$ & 2.38 & 0.590 & 3.26 & 0.85 & 2.38 \\
\hline S & 4.50 & 4.27 & 5.34 & 4.28 & 4.46 \\
\hline $\mathrm{NO}_{3}^{-}$ & 243 & 243 & Not analyzed & 241 & Not analyzed \\
\hline $\mathrm{NO}_{2}^{-}$ & 30.4 & 28.3 & Not analyzed & 24.9 & Not analyzed \\
\hline $\mathrm{Cl}$ & 2.42 & 2.35 & Not analyzed & 2.38 & Not analyzed \\
\hline $\mathrm{F}$ & 0.937 & $<0.30$ & Not analyzed & 0.29 & Not analyzed \\
\hline $\mathrm{CO}_{3}^{-2}$ & 44.5 & Not analyzed & Not analyzed & Not analyzed & Not analyzed \\
\hline TOC & 4.93 & 5.57 & Not analyzed & Not analyzed & Not analyzed \\
\hline $\mathrm{OH}^{-}$ & 12.9 & 21.6 & Not analyzed & Not analyzed & Not analyzed \\
\hline \multicolumn{2}{|c|}{ Spike Components } & & & & \\
\hline $\mathrm{Cr}$ & 0.844 & 0.870 & 0.997 & 0.733 & 0.708 \\
\hline $\mathrm{Ni}$ & 0.302 & $<0.0227$ & 0.468 & $<0.001$ & 0.244 \\
\hline $\mathrm{Pb}$ & 0.083 & 0.0657 & 0.113 & 0.069 & 0.070 \\
\hline $\mathrm{Cd}$ & 0.0280 & 0.000171 & 0.0155 & $<0.001$ & 0.022 \\
\hline I & 0.156 & 0.149 & Not analyzed & 0.142 & Not analyzed \\
\hline${ }^{99} \mathrm{Tc}$ & 0.0190 & Not analyzed & Not analyzed & Not added & Not added \\
\hline $\mathrm{U}$ & 0.278 & Not analyzed & Not analyzed & Not added & Not added \\
\hline
\end{tabular}


Table 3.8. Analytical Results for 5 M Na Overall Average Simulant Compositions

\begin{tabular}{|c|c|c|c|c|c|}
\hline \multirow[b]{2}{*}{ Component } & \multirow[b]{2}{*}{$\begin{array}{c}\text { Target } \\
(\mathrm{g} / \mathrm{L})\end{array}$} & \multicolumn{2}{|c|}{ PNNL } & \multicolumn{2}{|c|}{ SRNL } \\
\hline & & $\begin{array}{l}\text { Supernate } \\
(\mathrm{g} / \mathrm{L})\end{array}$ & $\begin{array}{l}\text { Total } \\
\text { (g/L) }\end{array}$ & $\begin{array}{c}\text { Supernate } \\
(\mathrm{g} / \mathrm{L})\end{array}$ & $\begin{array}{l}\text { Total } \\
\text { (g/L) }\end{array}$ \\
\hline \multicolumn{2}{|c|}{ Major Components } & & & 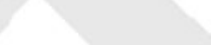 & 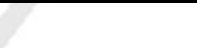 \\
\hline $\mathrm{Na}$ & 115 & 107 & 126 & 110 & 117 \\
\hline $\mathrm{Al}$ & 8.28 & 6.78 & 8.59 & 8.21 & 8.14 \\
\hline K & 1.28 & 1.30 & 1.19 & 1.40 & 1.42 \\
\hline P & 1.52 & 1.05 & 1.50 & 1.28 & 1.48 \\
\hline S & 2.74 & 2.69 & 3.23 & 2.71 & 2.73 \\
\hline $\mathrm{NO}_{3}^{-}$ & 101 & 100 & Not analyzed & 96.3 & Not analyzed \\
\hline $\mathrm{NO}_{2}^{-}$ & 26.0 & 23.6 & Not analyzed & 21.1 & Not analyzed \\
\hline $\mathrm{Cl}$ & 1.50 & 1.42 & Not analyzed & 1.43 & Not analyzed \\
\hline $\mathrm{F}$ & 0.600 & 0.411 & Not analyzed & 0.554 & Not analyzed \\
\hline $\mathrm{CO}_{3}^{-2}$ & 16.5 & Not analyzed & Not analyzed & Not analyzed & Not analyzed \\
\hline TOC & 0.921 & 0.993 & Not analyzed & Not analyzed & Not analyzed \\
\hline $\mathrm{OH}^{-}$ & 26.5 & 33.8 & Not analyzed & Not analyzed & Not analyzed \\
\hline \multicolumn{2}{|c|}{ Spike Components } & 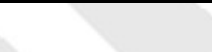 & & & \\
\hline $\mathrm{Cr}$ & 1.12 & 0.972 & 1.30 & 1.08 & 1.09 \\
\hline $\mathrm{Ni}$ & 0.194 & $<0.00227$ & 0.111 & $<0.001$ & 0.172 \\
\hline $\mathrm{Pb}$ & 0.053 & 0.0425 & 0.047 & 0.046 & 0.0467 \\
\hline Cd & 0.0179 & 0.000124 & 0.0014 & $<0.001$ & 0.0137 \\
\hline I & 0.100 & 0.0872 & Not analyzed & 0.0912 & Not analyzed \\
\hline${ }^{99} \mathrm{Tc}$ & 0.0122 & Not analyzed & Not analyzed & Not added & Not added \\
\hline $\mathrm{U}$ & 0.178 & Not analyzed & Not analyzed & Not added & Not added \\
\hline
\end{tabular}


Table 3.9. Analytical Results for 7.8 M Na Overall Average Simulant Compositions

\begin{tabular}{|c|c|c|c|c|c|}
\hline \multirow[b]{2}{*}{ Component } & \multirow[b]{2}{*}{$\begin{array}{c}\text { Target } \\
(\mathrm{g} / \mathrm{L})\end{array}$} & \multicolumn{2}{|c|}{ PNNL } & \multicolumn{2}{|c|}{ SRNL } \\
\hline & & $\begin{array}{l}\text { Supernate } \\
(\mathrm{g} / \mathrm{L})\end{array}$ & $\begin{array}{l}\text { Total } \\
\text { (g/L) }\end{array}$ & $\begin{array}{c}\text { Supernate } \\
(\mathrm{g} / \mathrm{L})\end{array}$ & $\begin{array}{l}\text { Total } \\
\text { (g/L) }\end{array}$ \\
\hline \multicolumn{2}{|c|}{ Major Components } & & & 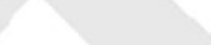 & 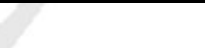 \\
\hline $\mathrm{Na}$ & 179 & 166 & 194 & 166 & 184 \\
\hline $\mathrm{Al}$ & 12.9 & 11.7 & 12.2 & 12.7 & 12.7 \\
\hline K & 2.00 & 1.97 & 1.86 & 2.28 & 2.33 \\
\hline $\mathrm{P}$ & 2.38 & $<0.489$ & 2.33 & 0.623 & 2.19 \\
\hline S & 4.28 & 3.94 & 4.93 & 3.50 & 4.26 \\
\hline $\mathrm{NO}_{3}^{-}$ & 157 & 156 & Not analyzed & 153 & Not analyzed \\
\hline $\mathrm{NO}_{2}^{-}$ & 40.5 & 35.2 & Not analyzed & 34.2 & Not analyzed \\
\hline $\mathrm{Cl}$ & 2.33 & 2.20 & Not analyzed & 2.28 & Not analyzed \\
\hline $\mathrm{F}$ & 0.937 & $<0.300$ & Not analyzed & 0.181 & Not analyzed \\
\hline $\mathrm{CO}_{3}^{-2}$ & 25.7 & Not analyzed & Not analyzed & Not analyzed & Not analyzed \\
\hline TOC & 1.44 & 1.94 & Not analyzed & Not analyzed & Not analyzed \\
\hline $\mathrm{OH}^{-}$ & 41.4 & 49.3 & Not analyzed & Not analyzed & Not analyzed \\
\hline \multicolumn{2}{|c|}{ Spike Components } & 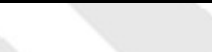 & & & \\
\hline $\mathrm{Cr}$ & 1.74 & 1.62 & 1.77 & 1.67 & 1.67 \\
\hline $\mathrm{Ni}$ & 0.302 & $<0.00227$ & 0.116 & $<0.001$ & 0.227 \\
\hline $\mathrm{Pb}$ & 0.083 & 0.081 & 0.082 & 0.070 & 0.068 \\
\hline Cd & 0.0280 & 0.000689 & 0.0050 & 0.007 & 0.021 \\
\hline I & 0.156 & 0.139 & Not analyzed & 0.143 & Not analyzed \\
\hline${ }^{99} \mathrm{Tc}$ & 0.0190 & Not analyzed & Not analyzed & Not added & Not added \\
\hline $\mathrm{U}$ & 0.278 & Not analyzed & Not analyzed & Not added & Not added \\
\hline
\end{tabular}




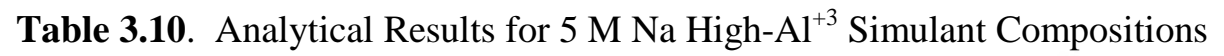

\begin{tabular}{|c|c|c|c|c|c|}
\hline \multirow[b]{2}{*}{ Component } & \multirow[b]{2}{*}{$\begin{array}{c}\text { Target } \\
(\mathrm{g} / \mathrm{L})\end{array}$} & \multicolumn{2}{|c|}{ PNNL } & \multicolumn{2}{|c|}{ SRNL } \\
\hline & & $\begin{array}{l}\text { Supernate } \\
\text { (g/L) }\end{array}$ & $\begin{array}{l}\text { Total } \\
(\mathrm{g} / \mathrm{L})\end{array}$ & $\begin{array}{l}\text { Supernate } \\
\text { (g/L) }\end{array}$ & $\begin{array}{l}\text { Total } \\
\text { (g/L) }\end{array}$ \\
\hline \multicolumn{6}{|c|}{ Major Components } \\
\hline $\mathrm{Na}$ & 115 & 112 & 122 & 110 & 116 \\
\hline $\mathrm{Al}$ & 15.1 & 13.3 & 14.5 & 14.4 & 14.3 \\
\hline K & 5.51 & 4.96 & 4.48 & 5.34 & 5.19 \\
\hline $\mathrm{P}$ & 0.817 & 0.525 & 0.695 & 0.740 & 0.784 \\
\hline S & 0.703 & 0.694 & 0.848 & 0.688 & 0.684 \\
\hline $\mathrm{NO}_{3}^{-}$ & 88.9 & 89.0 & Not analyzed & 85.0 & Not analyzed \\
\hline $\mathrm{NO}_{2}^{-}$ & 44.6 & 37.4 & Not analyzed & 37.2 & Not analyzed \\
\hline $\mathrm{Cl}$ & 3.23 & 3.14 & Not analyzed & 3.18 & Not analyzed \\
\hline $\mathrm{F}$ & 0.959 & 0.852 & Not analyzed & 0.898 & Not analyzed \\
\hline $\mathrm{CO}_{3}^{-2}$ & 11.9 & Not analyzed & Not analyzed & Not analyzed & Not analyzed \\
\hline TOC & 1.26 & 1.44 & Not analyzed & Not analyzed & Not analyzed \\
\hline $\mathrm{OH}^{-}$ & 24.9 & 33.5 & Not analyzed & Not analyzed & Not analyzed \\
\hline \multicolumn{6}{|c|}{ Spike Components } \\
\hline $\mathrm{Cr}$ & 1.12 & 1.02 & 1.16 & 1.08 & 1.06 \\
\hline $\mathrm{Ni}$ & 0.194 & $<0.00227$ & 0.0465 & $<0.001$ & 0.162 \\
\hline $\mathrm{Pb}$ & 0.053 & 0.052 & 0.0536 & 0.0455 & 0.0458 \\
\hline Cd & 0.0179 & 0.000317 & 0.00115 & $<0.001$ & 0.0133 \\
\hline I & 0.100 & 0.0893 & Not analyzed & 0.0928 & Not analyzed \\
\hline${ }^{99} \mathrm{Tc}$ & 0.0122 & Not analyzed & Not analyzed & Not added & Not added \\
\hline $\mathrm{U}$ & 0.178 & Not analyzed & Not analyzed & Not added & Not added \\
\hline
\end{tabular}




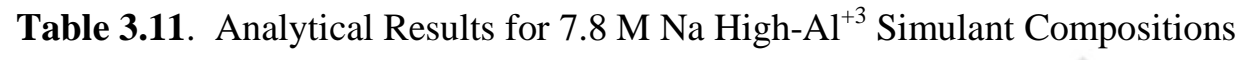

\begin{tabular}{|c|c|c|c|c|c|}
\hline \multirow[b]{2}{*}{ Component } & \multirow[b]{2}{*}{$\begin{array}{c}\text { Target } \\
(\mathrm{g} / \mathrm{L})\end{array}$} & \multicolumn{2}{|c|}{ PNNL } & \multicolumn{2}{|c|}{ SRNL } \\
\hline & & $\begin{array}{c}\text { Supernate } \\
(\mathrm{g} / \mathrm{L})\end{array}$ & $\begin{array}{l}\text { Total } \\
(\mathrm{g} / \mathrm{L})\end{array}$ & $\begin{array}{c}\text { Supernate } \\
(\mathrm{g} / \mathrm{L})\end{array}$ & $\begin{array}{l}\text { Total } \\
(\mathrm{g} / \mathrm{L})\end{array}$ \\
\hline \multicolumn{2}{|c|}{ Major Components } & & $x_{1}$ & & 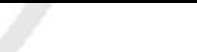 \\
\hline $\mathrm{Na}$ & 179 & 173 & 194 & 164 & 178 \\
\hline $\mathrm{Al}$ & 23.6 & 21.4 & 25.4 & 22.2 & 21.6 \\
\hline K & 8.60 & 6.81 & 7.03 & 8.01 & 7.69 \\
\hline $\mathrm{P}$ & 1.27 & $<0.489$ & 1.45 & 0.211 & 0.871 \\
\hline S & 1.10 & 0.547 & 1.31 & 0.679 & 1.06 \\
\hline $\mathrm{NO}_{3}^{-}$ & 139 & 149 & Not analyzed & 132 & Not analyzed \\
\hline $\mathrm{NO}_{2}^{-}$ & 69.5 & 55.8 & Not analyzed & 59.2 & Not analyzed \\
\hline $\mathrm{Cl}$ & 5.04 & 5.07 & Not analyzed & 5.00 & Not analyzed \\
\hline $\mathrm{F}$ & 1.50 & 0.708 & Not analyzed & 0.861 & Not analyzed \\
\hline $\mathrm{CO}_{3}^{-2}$ & 18.5 & Not analyzed & Not analyzed & Not analyzed & Not analyzed \\
\hline TOC & 1.96 & 5.45 & Not analyzed & Not analyzed & Not analyzed \\
\hline $\mathrm{OH}^{-}$ & 38.9 & 51.4 & Not analyzed & Not analyzed & Not analyzed \\
\hline \multicolumn{2}{|c|}{ Spike Components } & & & & \\
\hline $\mathrm{Cr}$ & 1.74 & 1.44 & 1.77 & 1.66 & 1.67 \\
\hline $\mathrm{Ni}$ & 0.302 & $<0.00227$ & 0.302 & $<0.001$ & 0.244 \\
\hline $\mathrm{Pb}$ & 0.083 & 0.0807 & 0.0839 & 0.0663 & 0.0671 \\
\hline Cd & 0.0280 & 0.00245 & 0.028 & 0.00717 & 0.0223 \\
\hline I & 0.156 & 0.136 & Not analyzed & 0.144 & Not analyzed \\
\hline${ }^{99} \mathrm{Tc}$ & 0.0190 & Not analyzed & Not analyzed & Not added & Not added \\
\hline $\mathrm{U}$ & 0.278 & Not analyzed & Not analyzed & Not added & Not added \\
\hline
\end{tabular}


Table 3.12. Analytical Results for $5 \mathrm{M} \mathrm{Na}$ High- $\mathrm{SO}_{4}{ }^{-2}$ Simulant Compositions

\begin{tabular}{|c|c|c|c|c|c|}
\hline \multirow[b]{2}{*}{ Component } & \multirow[b]{2}{*}{$\begin{array}{c}\text { Target } \\
\text { (g/L) }\end{array}$} & \multicolumn{2}{|c|}{ PNNL } & \multicolumn{2}{|c|}{ SRNL } \\
\hline & & $\begin{array}{l}\text { Supernate } \\
(\mathrm{g} / \mathrm{L})\end{array}$ & $\begin{array}{l}\text { Total } \\
\text { (g/L) }\end{array}$ & $\begin{array}{l}\text { Supernate } \\
\text { (g/L) }\end{array}$ & $\begin{array}{l}\text { Total } \\
\text { (g/L) }\end{array}$ \\
\hline \multicolumn{6}{|c|}{ Major Components } \\
\hline $\mathrm{Na}$ & 115 & 109 & 120 & 107 & 115 \\
\hline $\mathrm{Al}$ & 6.30 & 6.06 & 6.66 & 6.27 & 6.22 \\
\hline $\mathrm{P}$ & 1.52 & 1.01 & 0.998 & 0.819 & 1.33 \\
\hline S & 4.81 & 4.74 & 5.61 & 4.74 & 4.74 \\
\hline $\mathrm{NO}_{3}^{-}$ & 114 & 114 & Not analyzed & 110 & Not analyzed \\
\hline $\mathrm{NO}_{2}^{-}$ & 22.6 & 21.0 & Not analyzed & 17.8 & Not analyzed \\
\hline $\mathrm{Cl}$ & 1.23 & 1.14 & Not analyzed & 1.16 & Not analyzed \\
\hline $\mathrm{F}$ & 1.14 & 0.982 & Not analyzed & 0.937 & Not analyzed \\
\hline $\mathrm{CO}_{3}^{-2}$ & 10.4 & Not analyzed & Not analyzed & Not analyzed & Not analyzed \\
\hline TOC & 0.449 & 0.505 & Not analyzed & Not analyzed & Not analyzed \\
\hline $\mathrm{OH}^{-}$ & 26.0 & 29.1 & Not analyzed & Not analyzed & Not analyzed \\
\hline \multicolumn{6}{|c|}{ Spike Components } \\
\hline $\mathrm{Cr}$ & 1.12 & 1.14 & 1.20 & 1.07 & 1.06 \\
\hline $\mathrm{Ni}$ & 0.194 & $<0.00227$ & 0.120 & $<0.001$ & 0.167 \\
\hline $\mathrm{Pb}$ & 0.053 & 0.0517 & 0.0561 & 0.0449 & 0.0444 \\
\hline $\mathrm{Cd}$ & 0.0179 & 0.00084 & 0.0104 & $<0.001$ & 0.0152 \\
\hline I & 0.100 & 0.0891 & Not analyzed & 0.0906 & Not analyzed \\
\hline${ }^{99} \mathrm{Tc}$ & 0.0122 & Not analyzed & Not analyzed & Not added & Not added \\
\hline U & 0.178 & Not analyzed & Not analyzed & Not added & Not added \\
\hline
\end{tabular}


Table 3.13. Analytical Results for $7.8 \mathrm{M}$ Na High- $\mathrm{SO}_{4}{ }^{-2}$ Simulant Compositions

\begin{tabular}{|c|c|c|c|c|c|}
\hline \multirow[b]{2}{*}{ Component } & \multirow[b]{2}{*}{$\begin{array}{c}\text { Target } \\
(\mathrm{g} / \mathrm{L})\end{array}$} & \multicolumn{2}{|c|}{ PNNL } & \multicolumn{2}{|c|}{ SRNL } \\
\hline & & $\begin{array}{c}\text { Supernate } \\
(\mathrm{g} / \mathrm{L})\end{array}$ & $\begin{array}{l}\text { Total } \\
\text { (g/L) }\end{array}$ & $\begin{array}{c}\text { Supernate } \\
(\mathrm{g} / \mathrm{L})\end{array}$ & $\begin{array}{l}\text { Total } \\
\text { (g/L) }\end{array}$ \\
\hline \multicolumn{6}{|c|}{ Major Components } \\
\hline $\mathrm{Na}$ & 179 & 161 & 192 & 158 & 174 \\
\hline $\mathrm{Al}$ & 9.83 & 8.80 & 10.4 & 9.72 & 9.54 \\
\hline$P$ & 2.38 & 0.489 & 3.73 & 0.978 & 2.26 \\
\hline S & 7.50 & 5.74 & 8.81 & 5.33 & 7.22 \\
\hline $\mathrm{NO}_{3}^{-}$ & 177 & 177 & Not analyzed & 179 & Not analyzed \\
\hline $\mathrm{NO}_{2}^{-}$ & 35.3 & 31.9 & Not analyzed & 30.0 & Not analyzed \\
\hline $\mathrm{Cl}$ & 1.91 & 1.84 & Not analyzed & 1.87 & Not analyzed \\
\hline $\mathrm{F}$ & 1.78 & $<0.300$ & Not analyzed & $<0.1$ & Not analyzed \\
\hline $\mathrm{CO}_{3}^{-2}$ & 16.3 & Not analyzed & Not analyzed & Not analyzed & Not analyzed \\
\hline TOC & 0.701 & 0.741 & Not analyzed & Not analyzed & Not analyzed \\
\hline $\mathrm{OH}^{-}$ & 40.6 & 45.7 & Not analyzed & Not analyzed & Not analyzed \\
\hline \multicolumn{6}{|c|}{ Spike Components } \\
\hline $\mathrm{Cr}$ & 1.74 & 1.64 & 1.92 & 1.70 & 1.65 \\
\hline $\mathrm{Ni}$ & 0.302 & $<0.00227$ & 0.470 & $<0.001$ & 0.249 \\
\hline $\mathrm{Pb}$ & 0.083 & 0.082 & 0.0908 & 0.0709 & 0.0687 \\
\hline $\mathrm{Cd}$ & 0.0280 & 0.0007 & 0.0104 & 0.00476 & 0.0224 \\
\hline I & 0.156 & 0.140 & Not analyzed & 0.146 & Not analyzed \\
\hline${ }^{99} \mathrm{Tc}$ & 0.0190 & Not analyzed & Not analyzed & Not added & Not added \\
\hline $\mathrm{U}$ & 0.278 & Not analyzed & Not analyzed & Not added & Not added \\
\hline
\end{tabular}





\subsection{Summary}

Four LAW simulants have been developed for the initial screening tests of Cast Stone as a supplemental waste treatment technology. One simulant is an average composition based on chemical analyses of six saltcake samples from Hanford SSTs. This SST blend saltcake simulant was used in previous supplemental immobilization studies. The other simulants are based on HTWOS flowsheet model runs in support of the River Protection Project System Plan Revision 6 (Certa et al. 2011). Included are an overall average LAW simulant, a high-aluminum LAW simulant and a high-sulfate LAW simulant. These simulants were selected because it is known that aluminum and sulfate can impact the processing and waste form properties of Cast Stone. The simulants were prepared at two sodium concentrations, $5 \mathrm{M}$ and $7.8 \mathrm{M}$.

Before the simulant batches were prepared for the Cast Stone waste form screening tests, smaller one-liter batches were prepared to check for chemical interactions and solids formation. The SST blend saltcake and high-aluminum simulant had only minimal solids at $5 \mathrm{M} \mathrm{Na}$. The overall average and high-sulfate simulant had significant solids formation at $5 \mathrm{M}$ Na. These solids were determined to contain sodium fluorophosphates similar to what had been observed earlier when the SST blend saltcake simulant was initially developed. Therefore, the fluoride and phosphate levels were reduced in the overall average and high-sulfate simulants to levels that would result in little to no solids formation at $5 \mathrm{M} \mathrm{Na}$ concentration. All of the simulants had solids formation at 7.8 $\mathrm{M} \mathrm{Na}$. Based on supernate analyses, all four 7.8 M Na simulants appear to have precipitated sodium fluorophosphate solids. These solids were left in the final simulant batches used to make the Cast Stone waste forms for the screening tests.

This approach was taken in large part because it would be consistent with the proposed process operations for supplemental treatment of Hanford LAW. Tank waste supernatant and dissolved saltcake solutions are planned to be adjusted to approximately $5 \mathrm{M}$ Na concentration and filtered to remove solids prior to cesium removal via ion exchange. This would yield solids-free liquids at specific gravities that would not plug the ion exchange columns or float the ion exchange resin. Any solids present in the real waste at this sodium concentration would be removed by the pretreatment filtration process. After cesium removal, the residual waste liquids could be concentrated in an evaporator prior to immobilization in order to increase waste loading in the final waste form. If solids formed at that point it would be extra work to remove the solids, and recycling the solids to the DSTs would simply add to the final treated waste volume. Rather, it would be preferable for the immobilization process to be sufficiently robust to be able to treat the waste with modest amounts of solids present and still produce a compliant waste form. Accordingly, for this work we elected to develop simulants at or near saturation at $5 \mathrm{M}$ Na concentration then use the same compositions, concentrated to $7.8 \mathrm{M} \mathrm{Na}$, and retain any solids that formed at the higher concentration for use in testing the robustness of the immobilization process.

Table 4.1 and Table 4.2 show the final simulant target moles/mole Na concentrations for the major constituents and selected COCs, respectively, in the four LAW simulants that will be used for the Cast Stone waste form screening tests. The target concentrations in Table 4.1 have been charge balanced. 
Table 4.1. Final LAW Simulants for Cast Stone Screening Tests

\begin{tabular}{|c|c|c|c|c|}
\hline & $\begin{array}{c}\text { SST Blend } \\
\text { Saltcake }\end{array}$ & $\begin{array}{c}\text { HTWOS } \\
\text { Overall } \\
\text { Average }\end{array}$ & $\begin{array}{c}\text { HTWOS } \\
\text { High } \\
\text { Al, Cl }\end{array}$ & $\begin{array}{c}\text { HTWOS } \\
\text { High } \\
\mathrm{SO}_{4}\end{array}$ \\
\hline Waste Constituent & \multicolumn{4}{|c|}{ Concentration (moles/mole $\mathrm{Na})^{(\mathrm{a})}$} \\
\hline $\mathrm{Na}$ & 1.000 & 1.000 & 1.000 & 1.000 \\
\hline K & 0.002 & 0.007 & 0.028 & - \\
\hline $\mathrm{Al}$ & 0.013 & 0.061 & 0.112 & 0.047 \\
\hline $\mathrm{Cl}$ & 0.009 & 0.008 & 0.018 & 0.007 \\
\hline $\mathrm{F}$ & 0.006 & $0.006^{(\mathrm{b})}$ & 0.010 & $0.012^{(b)}$ \\
\hline $\mathrm{SO}_{4}$ & 0.018 & 0.017 & 0.004 & 0.030 \\
\hline $\mathrm{PO}_{4}$ & 0.010 & $0.010^{(\mathrm{b})}$ & 0.005 & $0.010^{(\mathrm{b})}$ \\
\hline $\mathrm{NO}_{2}$ & 0.085 & 0.113 & 0.194 & 0.098 \\
\hline $\mathrm{NO}_{3}$ & 0.502 & 0.324 & 0.287 & 0.367 \\
\hline $\mathrm{CO}_{3}$ & 0.095 & 0.055 & 0.040 & 0.035 \\
\hline TOC Total & 0.057 & 0.015 & 0.021 & 0.007 \\
\hline Free $\mathrm{OH}$ & 0.097 & 0.312 & 0.293 & 0.306 \\
\hline
\end{tabular}

(a) After charge balancing.

(b) Concentration of $\mathrm{F}$ and $\mathrm{PO}_{4}{ }^{3-}$ reduced from HTWOS values because of solids formation observed in preliminary simulants.

Table 4.2. Final Spike Levels for Hazardous Constituents and Radionuclides for Cast Stone Screening Test Simulants

\begin{tabular}{|c|c|c|c|}
\hline Waste Constituent & $\begin{array}{c}\text { HTWOS } \\
\text { Overall } \\
\text { Average }\end{array}$ & $\begin{array}{l}\text { HTWOS } \\
\text { Maximum }\end{array}$ & $\begin{array}{c}\text { Other } \\
\text { Considerations }\end{array}$ \\
\hline RCRA Metals and UHC & moles/mole $\mathrm{Na}$ & moles/mole $\mathrm{Na}$ & moles/mole Na \\
\hline $\mathrm{Cd}$ & $2.78 \mathrm{E}-06$ & $3.19 \mathrm{E}-05$ & - \\
\hline $\mathrm{Cr}$ & $2.42 \mathrm{E}-03$ & $9.99 \mathrm{E}-03$ & $4.30 \mathrm{E}-03^{(\mathrm{a})}$ \\
\hline $\mathrm{Pb}$ & $1.16 \mathrm{E}-05$ & $5.13 \mathrm{E}-05$ & - \\
\hline $\mathrm{Ni}$ & $6.41 \mathrm{E}-05$ & $6.61 \mathrm{E}-04$ & - \\
\hline Radionuclides & $\mathrm{Ci} / \mathrm{mole} \mathrm{Na}$ & $\mathrm{Ci} / \mathrm{mole} \mathrm{Na}$ & $\mathrm{Ci} / \mathrm{mole} \mathrm{Na}$ \\
\hline${ }^{99} \mathrm{Tc}$ & $1.13 \mathrm{E}-05$ & $4.13 \mathrm{E}-05$ & - \\
\hline${ }^{99} \mathrm{Tc}^{(\mathrm{c})}$ & $\begin{array}{c}(6.65 E+02 \\
\mu \mathrm{g} / \mathrm{mole} \mathrm{Na})\end{array}$ & $\begin{array}{c}(2.43 \mathrm{E}+03 \\
\mu \mathrm{g} / \mathrm{mole} \mathrm{Na})\end{array}$ & - \\
\hline${ }^{129} \mathrm{I}$ & $1.44 \mathrm{E}-08$ & $8.01 \mathrm{E}-08$ & $3.54 \mathrm{E}-06^{(\mathrm{b})}$ \\
\hline${ }^{127}$ I (stable) ${ }^{(\mathrm{c})}$ & $\begin{array}{c}(8.14 \mathrm{E}+01 \\
\mu \mathrm{g} / \mathrm{mole} \mathrm{Na})\end{array}$ & $\begin{array}{c}(4.53 E+02 \\
\mu \mathrm{g} / \mathrm{mole} \mathrm{Na})\end{array}$ & $\begin{array}{c}(2.00 \mathrm{E}+04 \\
\mu \mathrm{g} / \mathrm{mole} \mathrm{Na})\end{array}$ \\
\hline${ }^{232+233+234+235+236+238} \mathrm{U}$ & $1.59 \mathrm{E}-08$ & $5.63 \mathrm{E}-08$ & - \\
\hline Natural or depleted $U^{(c)}$ & & $\begin{array}{c}(3.56+04 \\
\mu \mathrm{g} / \mathrm{mole} \mathrm{Na})\end{array}$ & - \\
\hline
\end{tabular}

(a) Cr concentration adjusted based on review of best basis inventory and previous simulant work.

(b) I concentration increased to address possible detection limits in waste form leach tests. Iodine added as nonradioactive ${ }^{127} \mathrm{I}$.

(c) These COCs will be added to simulants based on mass (as shown). 


\subsection{References}

ANS. 2009. Measurement of the Leachability of Solidified Low-Level Radioactive Wastes by a Short-Term Test Procedure. ANS/ANSI 16.1, American Nuclear Society, La Grange Park, Illinois.

Certa PJ, PA Empey, and MN Wells. 2011. River Protection Project System Plan. ORP-11242, Revision 6, Washington River Protection Solutions, LLC, Richland, Washington.

Crawford TL, Meinert F, Allen GK and DJ Swanberg. 2012a. Modeling Modification Request Breakout of LAW Feed Compositions, MMR-12-014, Rev. 0, Washington River Protection Solutions, Richland, Washington.

Crawford TL, Feero AJ, Allen GK and DJ Swanberg. 2012b. Modeling Modification Request Initiative \#5 Tc Removal/Immobilization, MMR-12-028, Rev. 0, Washington River Protection Solutions, Richland, Washington.

EPA. 1992. Toxicity Characteristic Leaching Procedure. EPA Method 1311, Revision 0, U.S. Environmental Protection Agency, Washington, D.C.

EPA. 2009. Mass Transfer Rates of Constituents in Monolith or Compacted Granular Materials Using a Semi-Dynamic Tank Leaching Test. EPA Draft Method 1315, U.S. Environmental Protection Agency, Washington, D.C.

Feero AJ. 2012. MMR-12-028 Additional Requested Output, SVF-2616, Rev. 0, Washington River Protection Solutions, Richland, Washington.

Gasper, KA, KD Boomer, ME Johnson, GW Reddick, Jr., AF Choho, and JS Garfield, 2002, Recommendation for Supplemental Technologies for Potential Mission Acceleration, RPP-11261, Revision 0, CH2MHill Hanford Group, Inc., Richland, Washington.

Mattigod SV, JH Westsik, Jr., CW Chung, MJ Lindberg, and KE Parker. 2011. Waste Acceptance Testing of Secondary Waste Forms: Cast Stone, Ceramicrete and DuraLith. PNNL-20632, Pacific Northwest National Laboratory, Richland, Washington.

Rapko, BM, SI Sinkov and TG Levitskaia, 2003, Removal of ${ }^{137} \mathrm{Cs}$ from Dissolved Hanford Tank Saltcake by Treatment with IE-911, PNNL-14250, Revision 1, Pacific Northwest National Laboratory, Richland, Washington.

Rassat SD, LA Mahoney, RL Russell, SA Bryan, and RL Sell. 2003. Cold Dissolved Saltcake Simulant Development, Preparation, and Analysis. PNNL-14194, Rev 1, Pacific Northwest National Laboratory, Richland, Washington.

RCRA—Resource Conservation and Recovery Act of 1976. 1976. Public Law 94-580, as amended, 42 USC 6901 et seq. and 42 USC 6927(c) et seq.

Sundaram, SK, KE Parker, ME Valenta, SG Pitman, J Chun, C-W Chung, ML Kimura, CA Burns, W Um, and JH Westsik, Jr. 2011. Secondary Waste Form Development and Optimization-Cast Stone. PNNL-20159, Rev. 1, Pacific Northwest National Laboratory, Richland, Washington. 
Westsik JH, Jr., RJ Serne, EM Pierce, A Cozzi, CW Chung, and DJ Swanberg. 2012. Supplemental Immobilization Cast Stone Technology Development and Waste Form Qualification Testing Plan. PNNL-21823, Pacific Northwest National Laboratory, Richland, Washington. 


\section{Appendix}

\section{Summary of SRNL Simulant Development}





\section{Appendix}

\section{Summary of SRNL Simulant Development}

\section{A.1 Simulant Development}

Simulant development began by taking molar ratio compositions from Table 2.2 and independently checking the charge balance for the composition and adjusting the anions as needed to obtain a charge balance. The compounds to be used in the recipe were then chosen and the recipe calculated. At that point, the Savannah River National Laboratory (SRNL) recipe was compared to the proposed Pacific Northwest National Laboratory (PNNL) recipe and, for each component, there was generally less than $0.05 \mathrm{~g}$ difference. For each salt solution recipe, an initial batch of simulant was prepared in a volumetric flask. The density of the resulting solution or slurry was measured using a densitometer and the weight percent total solids was measured on a heated balance. For high-concentration caustic salt solutions, a polymethylpentene volumetric flask was used to prevent leaching of species from laboratory glassware. Once the density was available, the simulant recipe was converted to a mass-based recipe to allow production of large batch sizes without having to measure the volume.

The initial simulant prepared by SRNL was the 5 molar (M) Na, Hanford Tank Waste Operations Simulator (HTWOS). Overall Average simulant to confirm the observation of solids noted by PNNL. The salt solution prepared by SRNL also showed solids as can be seen in Figure A.1.

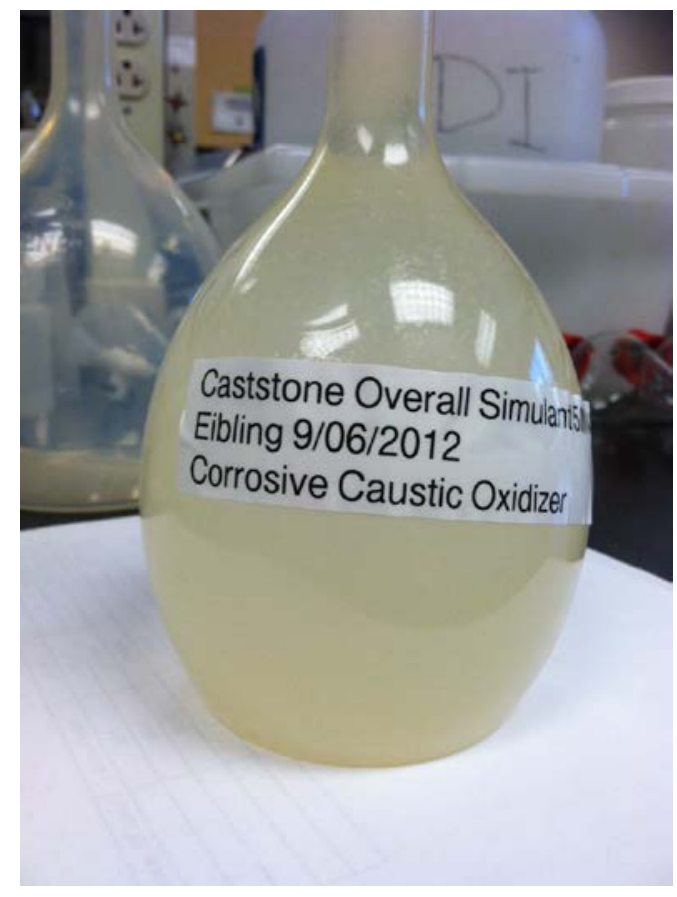

Figure A.1. Initial Overall Average $5 \mathrm{M}$ Na Simulant 
The 7.8 M Na Overall Average simulant also contained a substantial amount of solids. Analysis of the supernate phase confirmed that the phosphate was present in the supernate at only $24 \%$ of the target value and the fluoride was below detection level as discussed in Section 3.3.

The next simulant tested was the HTWOS High-SO $\mathrm{S}_{4}$ simulant at 5.0 M Na. Since the presence of fluoride was a known issue for phosphate, the fluoride in the recipe was not added, to determine whether the high level of phosphate could be reached in the absence of the fluoride interference. Figure A.2 shows that the High- $\mathrm{SO}_{4}$ simulant has a large quantity of undissolved solids, presumably due to phosphate, even without the fluoride.

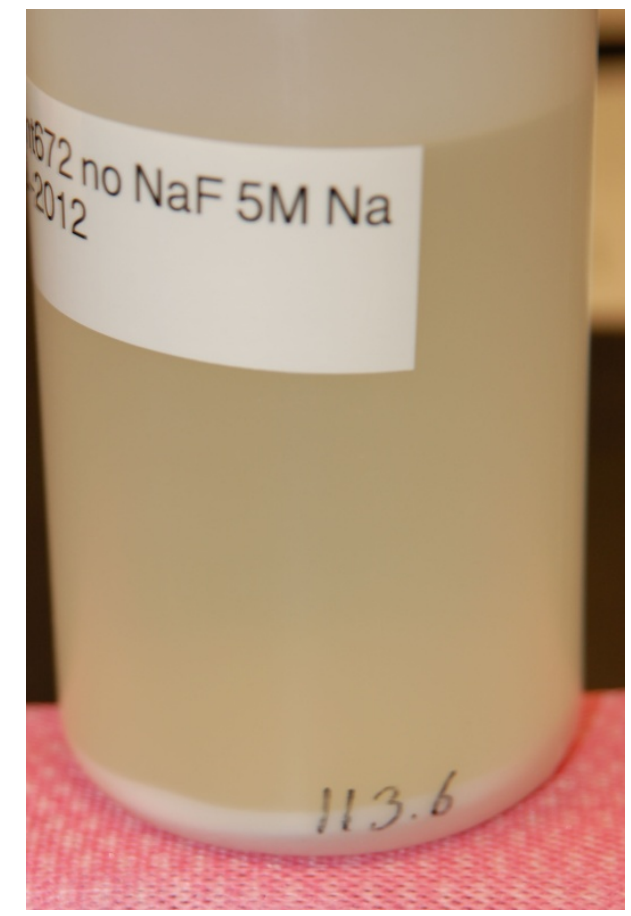

Figure A.2. $5 \mathrm{M} \mathrm{High-SO}_{4}$ Simulant with No Fluoride Added

Subsequent testing by PNNL and discussions with the customer led to a reduction in the concentrations of phosphate and fluoride to levels similar to those in the single-shell tank (SST) Blend Saltcake simulant at 5.0 M Na. New recipes were independently generated using the adjusted compositions with the reduced levels of phosphate and fluoride. New one-liter batches were prepared of the 5.0 $\mathrm{M}$ and 7.8 $\mathrm{M} \mathrm{Na}$ High-SO 4 simulants and the densities measured.

\section{A.2 Large-Scale Simulants}

The large batches of simulants required for fresh Cast Stone grout properties and performance testing were prepared using mass-driven recipes based on the measured densities from the small one-liter batches described above. The large batches were prepared in 10, 15, or 25 liter polypropylene carboys using an overhead, variable speed mixer to dissolve the added salts. The batch carboy was then moved to a secondary containment vessel for heated mixing. Mixing was provided by a speed-controlled, overhead mixer using the elliptical agitator made by SRNL shown in Figure A.3. 


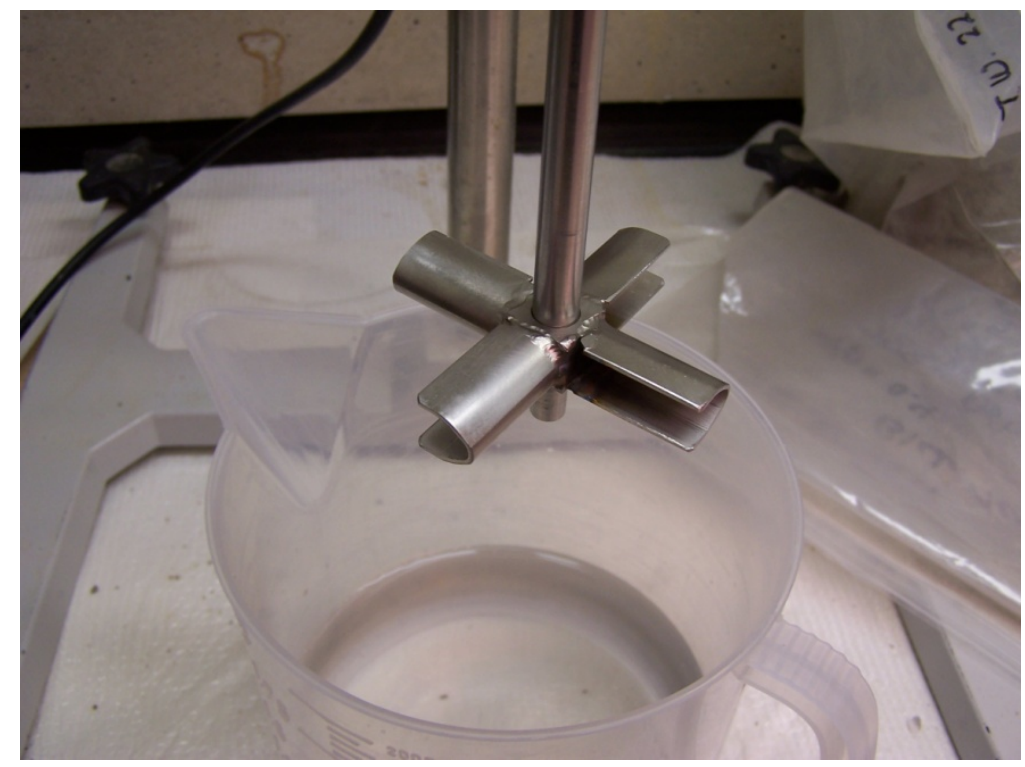

Figure A.3. Elliptical Agitator Blade

Heating was provided by a Neslab RTE 111 temperature-controlled circulator attached to a $1 / 4$ inch stainless steel coil shown in Figure A.4. The $5 \mathrm{M}$ Na simulants were heated to $60^{\circ} \mathrm{C}$ for two hours with active mixing. The $7.8 \mathrm{M}$ Na simulants were heated to $80^{\circ} \mathrm{C}$ for two hours while mixing.

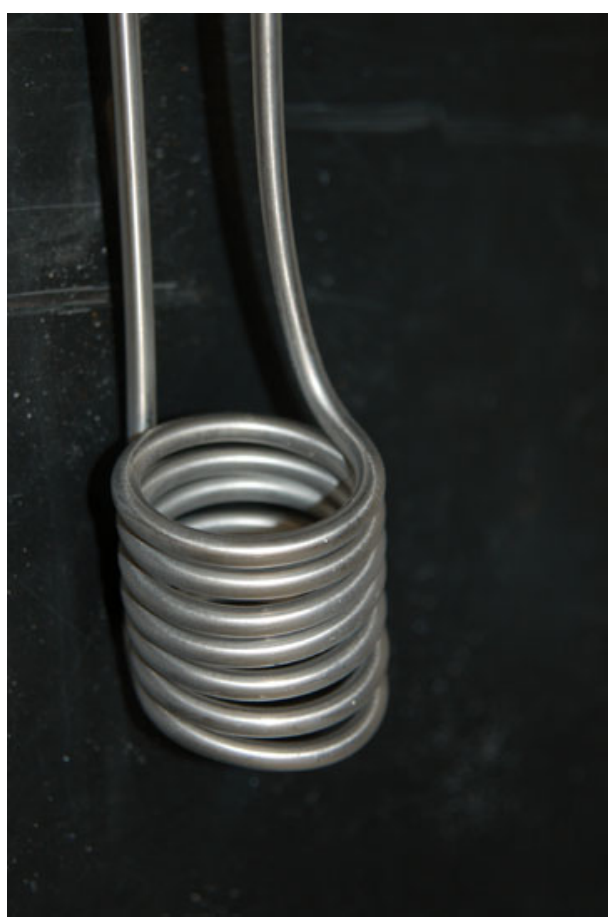

Figure A.4. Heating Coil 


\section{A.3 Resource Conservation and Recovery Act (RCRA) Additions}

The planned leach tests for the SRNL Cast Stone grout required the addition of cadmium, chromium (as chromate), lead, nickel, and iodide to the Cast Stone simulants. Sodium chromate and sodium iodide are very soluble in caustic solutions so these compounds were directly added to the mixing simulants at the appropriate spiking level. The cadmium, nickel, and lead were added as nitrates; however, direct addition might have coated the surface of the salt crystals with the insoluble hydroxide or oxide form and prevented complete dissolution of the specific nitrate salt. Therefore, all three nitrate salts were first dissolved in 20 to $30 \mathrm{~mL}$ of deionized water prior to addition to the simulant. For the 5.0 M Na SST Blend Saltcake simulant spiked with the nitrate solution, the solution was added by dripping onto the mixing simulant surface. This generated floating precipitated solids that collected on the agitator shaft and at the wall of the mixing vessel. The rest of the large batch simulants were spiked by using a transfer pipet to inject the metal nitrate spiking solution below the liquid surface near the vortex created by the elliptical mixer. This approach resulted in a better dispersion of the precipitated metals as long as the simulant was actively mixed. Figure A.5 and Figure A.6 show the final spiked simulants after settling with the layer of nickel hydroxide at the bottom of the container.

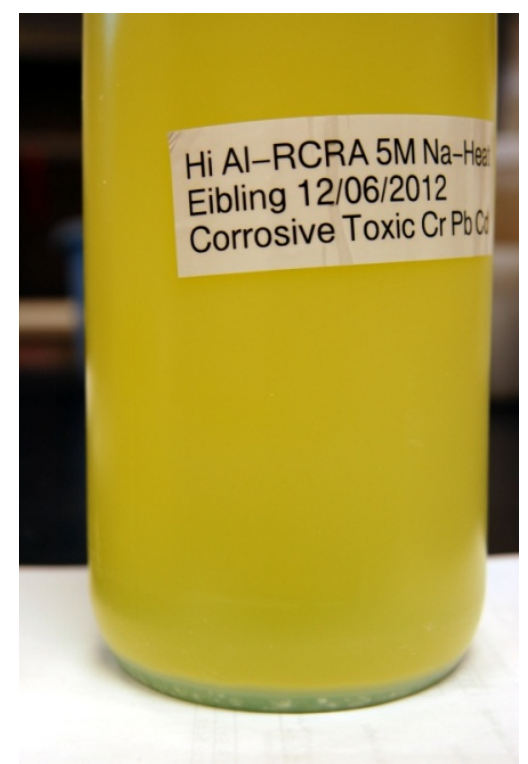

Figure A.5. High-Al RCRA 5 M Na Simulant 


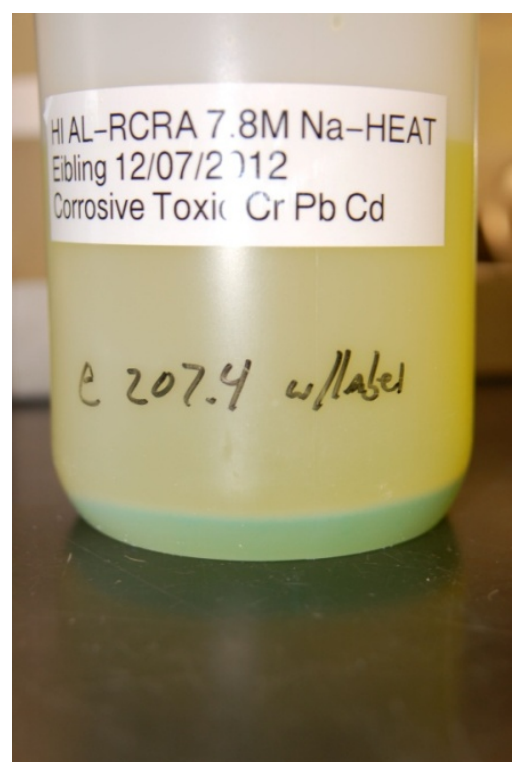

Figure A.6. High-Al RCRA 7.8 M Na Simulant 




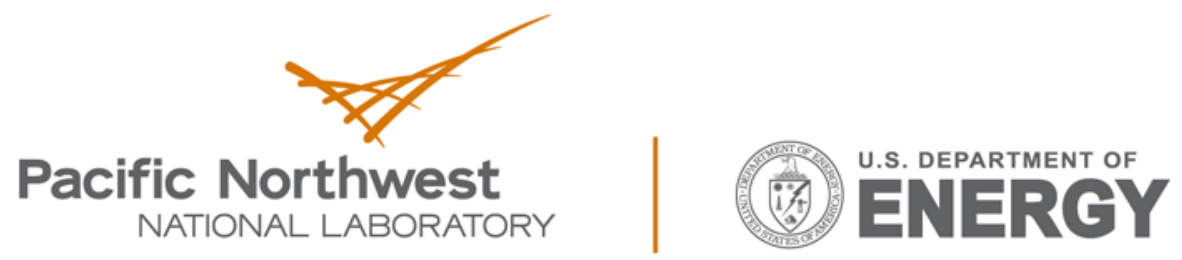

Proudly Operated by Battelle Since 1965

902 Battelle Boulevard

P.O. Box 999

Richland, WA 99352

1-888-375-PNNL (7665)

www.pnnl.gov 